\title{
LEVEL II SCOUR ANALYSIS FOR BRIDGE 6 (MAIDTH00050006) on TOWN HIGHWAY 5, crossing CUTLER MILL BROOK, MAIDSTONE, VERMONT
}

Open-File Report 98-419

Prepared in cooperation with

VERMONT AGENCY OF TRANSPORTATION

and

FEDERAL HIGHWAY ADMINISTRATION

U.S. Department of the Interior U.S. Geological Survey

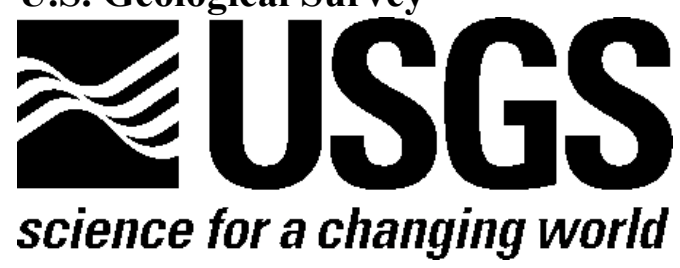




\section{LEVEL II SCOUR ANALYSIS FOR BRIDGE 6 (MAIDTH00050006) on TOWN HIGHWAY 5, crossing CUTLER MILL BROOK, MAIDSTONE, VERMONT \\ By LORA K. STRIKER}

U.S. Geological Survey Open-File Report 98-419

Prepared in cooperation with

VERMONT AGENCY OF TRANSPORTATION

and

FEDERAL HIGHWAY ADMINISTRATION 


\title{
U.S. DEPARTMENT OF THE INTERIOR BRUCE BABBITT, Secretary
}

\author{
U.S. GEOLOGICAL SURVEY
}

Thomas J. Casadevall, Acting Director

For additional information write to:

District Chief

U.S. Geological Survey 361 Commerce Way

Pembroke, NH 03275-3718
Copies of this report may be purchased from:

U.S. Geological Survey

Branch of Information Services

Open-File Reports Unit

Box 25286

Denver, CO 80225-0286 


\section{CONTENTS}

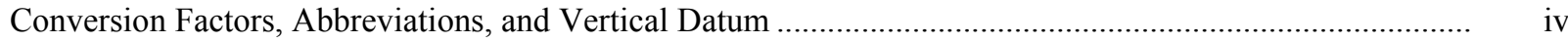

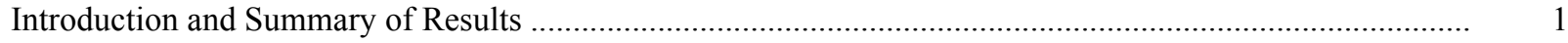

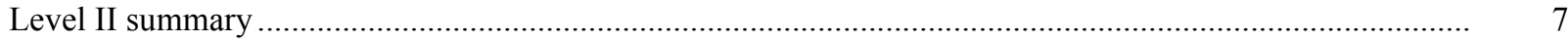

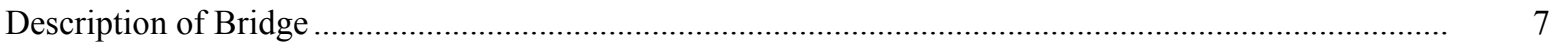

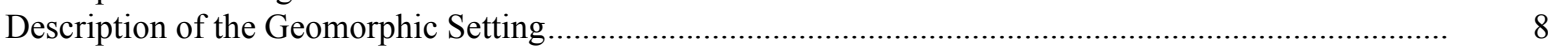

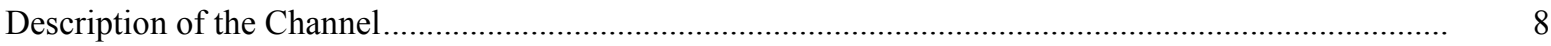

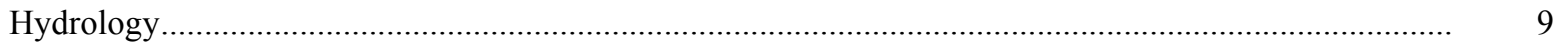

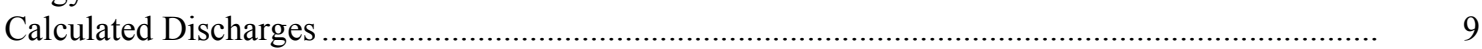

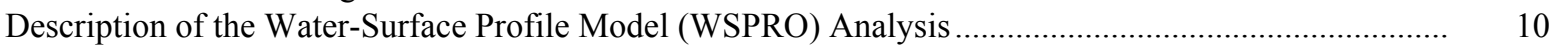

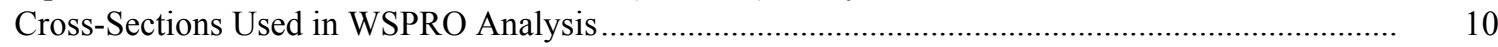

Data and Assumptions Used in WSPRO Model ........................................................................ 11

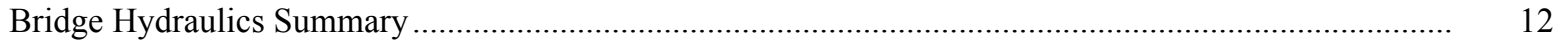

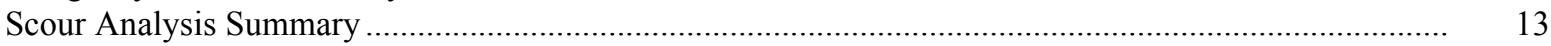

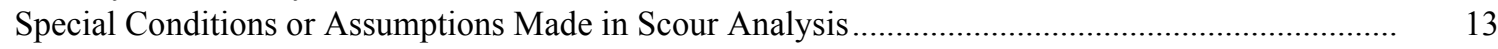

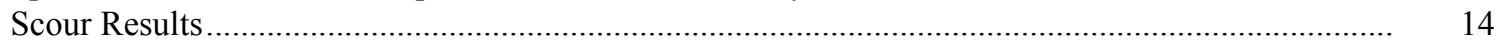

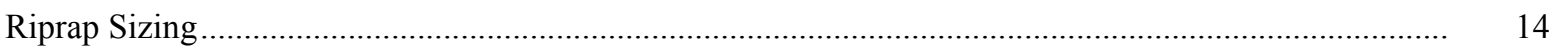

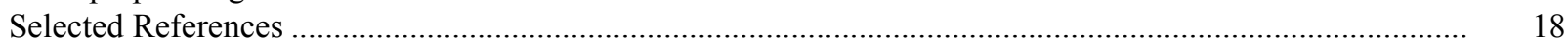

Appendices:

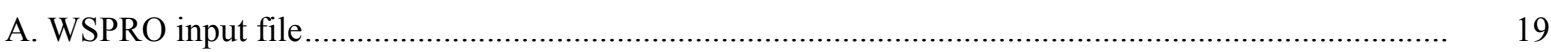

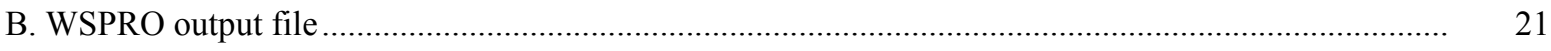

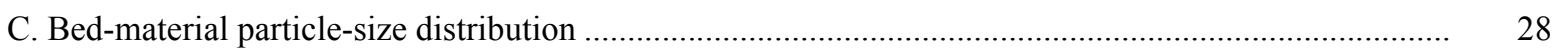

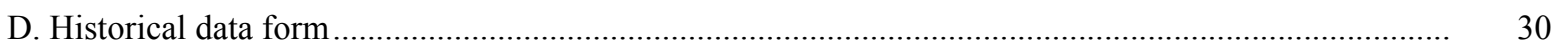

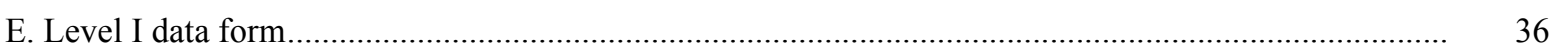

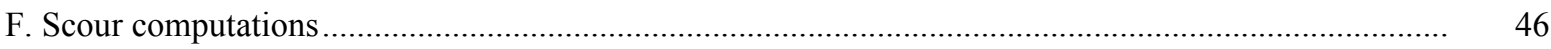

\section{FIGURES}

1. Map showing location of study area on USGS 1:24,000 scale map

2. Map showing location of study area on Vermont Agency of Transportation town highway map

3. Structure MAIDTH00050006 viewed from upstream (July 13, 1995).

4

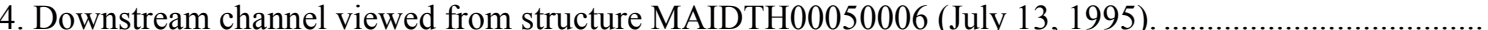

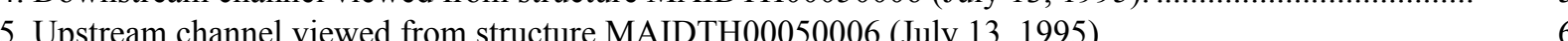

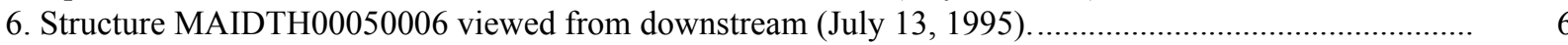

7. Water-surface profiles for the 100- and 500-year discharges at structure MAIDTH00050006 on Town Highway 5, crossing Cutler Mill Brook, Maidstone, Vermont.

8. Scour elevations for the 100-year discharge at structure

MAIDTH00050006 on Town Highway 5, crossing Cutler Mill Brook,

Maidstone, Vermont.

\section{TABLES}

1. Remaining footing/pile depth at abutments for the 100-year discharge at structure MAIDTH00050006 on Town Highway 5, crossing Cutler Mill Brook, Maidstone, Vermont.

2. Remaining footing/pile depth at abutments for the 500-year discharge at structure MAIDTH00050006 on Town Highway 5, crossing Cutler Mill Brook, Maidstone, Vermont. 


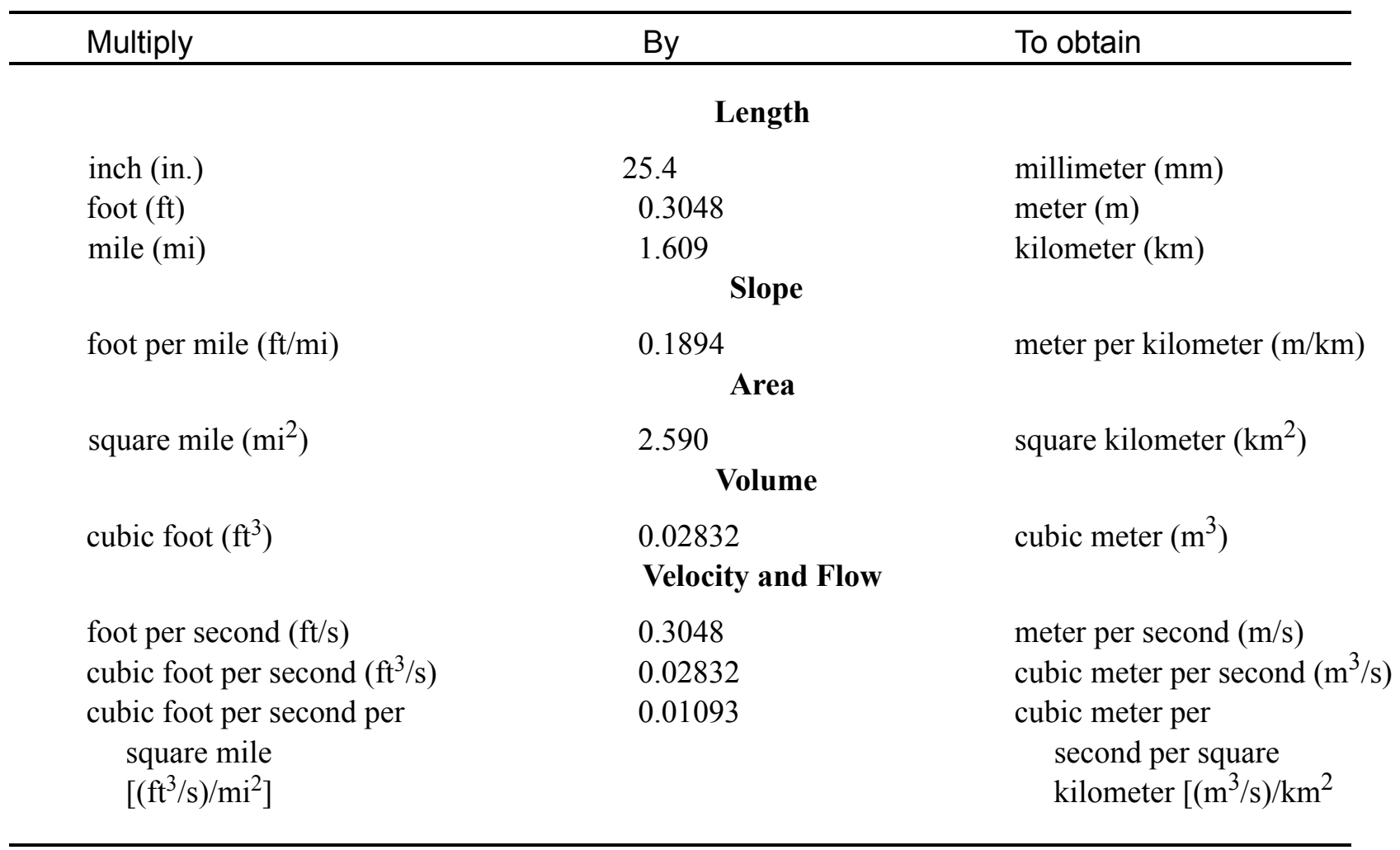

\section{OTHER ABBREVIATIONS}

$\begin{array}{lrlr}\mathrm{BF} & \text { bank full } & \text { LWW } & \text { left wingwall } \\ \mathrm{cfs} & \text { cubic feet per second } & \text { Max } & \text { maximum } \\ \mathrm{D}_{50} & \text { median diameter of bed material } & \text { MC } & \text { main channel } \\ \mathrm{DS} & \text { downstream } & \text { RAB } & \text { right abutment } \\ \mathrm{elev} & \text { elevation } & \text { RABUT } & \text { face of right abutment } \\ \mathrm{f} / \mathrm{p} & \text { flood plain } & \text { RB } & \text { right bank } \\ \mathrm{ft} & \text { square feet } & \text { ROB } & \text { right overbank } \\ \mathrm{ft} / \mathrm{ft} & \text { feet per foot } & \text { RWW } & \text { right wingwall } \\ \mathrm{FEMA} & \text { Federal Emergency Management Agency } & \text { TH } & \text { town highway } \\ \mathrm{FHWA} & \text { Federal Highway Administration } & \text { UB } & \text { under bridge } \\ \mathrm{JCT} & \text { junction } & \text { US } & \text { upstream } \\ \text { LAB } & \text { left abutment } & \text { USGS } & \text { United States Geological Survey } \\ \text { LABUT } & \text { face of left abutment } & \text { VTAOT } & \text { Vermont Agency of Transportation } \\ \text { LB } & \text { left bank } & \text { WSPRO } & \text { water-surface profile model } \\ \text { LOB } & \text { left overbank } & \text { yr } & \text { year }\end{array}$

In this report, the words "right" and "left" refer to directions that would be reported by an observer facing downstream. Sea level: In this report, "sea level" refers to the National Geodetic Vertical Datum of 1929-- a geodetic datum derived from a general adjustment of the first-order level nets of the United States and Canada, formerly called Sea Level Datum of 1929.

In the appendices, the above abbreviations may be combined. For example, USLB would represent upstream left bank. 


\title{
LEVEL II SCOUR ANALYSIS FOR BRIDGE 6 (MAIDTH00050006) ON TOWN HIGHWAY 5, CROSSING CUTLER MILL BROOK, MAIDSTONE, VERMONT
}

\author{
By Lora K. Striker
}

\section{INTRODUCTION AND SUMMARY OF RESULTS}

This report provides the results of a detailed Level II analysis of scour potential at structure MAIDTH00050006 on Town Highway 5 crossing Cutler Mill Brook, Maidstone, Vermont (figures 1-8). A Level II study is a basic engineering analysis of the site, including a quantitative analysis of stream stability and scour (FHWA, 1993). Results of a Level I scour investigation also are included in appendix $\mathrm{E}$ of this report. A Level I investigation provides a qualitative geomorphic characterization of the study site. Information on the bridge, gleaned from Vermont Agency of Transportation (VTAOT) files, was compiled prior to conducting Level I and Level II analyses and is found in appendix D.

The site is in the White Mountain section of the New England physiographic province in northeastern Vermont. The $14.7-\mathrm{mi}^{2}$ drainage area is in a predominantly rural and forested basin. In the vicinity of the study site, the surface cover is predominantly forest with some pasture upstream on the left bank.

In the study area, Cutler Mill Brook has an incised, straight channel with a slope of approximately $0.014 \mathrm{ft} / \mathrm{ft}$, an average channel top width of $47 \mathrm{ft}$ and an average bank height of $7 \mathrm{ft}$. The channel bed material ranges from gravel to boulder with a median grain size $\left(\mathrm{D}_{50}\right)$ of $92.4 \mathrm{~mm}(0.303 \mathrm{ft})$. The geomorphic assessment at the time of the Level I and Level II site visit on July 13, 1995, indicated that the reach was stable.

The Town Highway 5 crossing of Cutler Mill Brook is a 25-ft-long, one-lane bridge consisting of one 23-foot concrete slab span (Vermont Agency of Transportation, written communication, August 5, 1994). The opening length of the structure parallel to the bridge face is $20.7 \mathrm{ft}$. The bridge is supported by vertical, concrete abutments with wingwalls. The channel is skewed approximately 35 degrees to the opening while the computed openingskew-to-roadway is 25 degrees. 
A scour hole $1.5 \mathrm{ft}$ deeper than the mean thalweg depth was observed in the middle of the channel $36 \mathrm{ft}$ downstream of the bridge. Scour protection measures at the site included type4 stone fill (less than 60 inches diameter) along the left and right banks upstream and the right bank downstream; type-3 stone fill (less than 48 inches diameter) along the entire base length of the upstream left and right wingwalls, the left and right abutments, and the downstream left wingwall. Type-3 stone fill was also observed at the downstream end of the downstream right wingwall and along the left bank downstream. Additional details describing conditions at the site are included in the Level II Summary and appendices D and E.

Scour depths and recommended rock rip-rap sizes were computed using the general guidelines described in Hydraulic Engineering Circular 18 (Richardson and Davis, 1995) for the 100- and 500-year discharges. In addition, the incipient roadway-overtopping discharge was determined and analyzed as another potential worst-case scour scenario. Total scour at a highway crossing is comprised of three components: 1) long-term streambed degradation; 2) contraction scour (due to accelerated flow caused by a reduction in flow area at a bridge) and; 3 ) local scour (caused by accelerated flow around piers and abutments). Total scour is the sum of the three components. Equations are available to compute depths for contraction and local scour and a summary of the results of these computations follows.

Contraction scour for all modelled flows ranged from 0.9 to $1.0 \mathrm{ft}$. The worst-case contraction scour occurred at the 100-year discharge. Abutment scour ranged from 7.7 to $11.4 \mathrm{ft}$. The worst-case abutment scour occurred at the 500-year discharge at the left abutment and at the 100-year discharge at the right abutment. Additional information on scour depths and depths to armoring are included in the section titled "Scour Results". Scoured-streambed elevations, based on the calculated scour depths, are presented in tables 1 and 2. A cross-section of the scour computed at the bridge is presented in figure 8 . Figure 8 shows only the 100-year discharge scour elevations since total scour depths computed for the 100-year discharge were greater than those for the 500-year discharge. Scour depths were calculated assuming an infinite depth of erosive material and a homogeneous particlesize distribution.

It is generally accepted that the Froehlich equation (abutment scour) gives "excessively conservative estimates of scour depths" (Richardson and Davis, 1995, p. 46). Usually, computed scour depths are evaluated in combination with other information including (but not limited to) historical performance during flood events, the geomorphic stability assessment, existing scour protection measures, and the results of the hydraulic analyses. Therefore, scour depths adopted by VTAOT may differ from the computed values documented herein. 


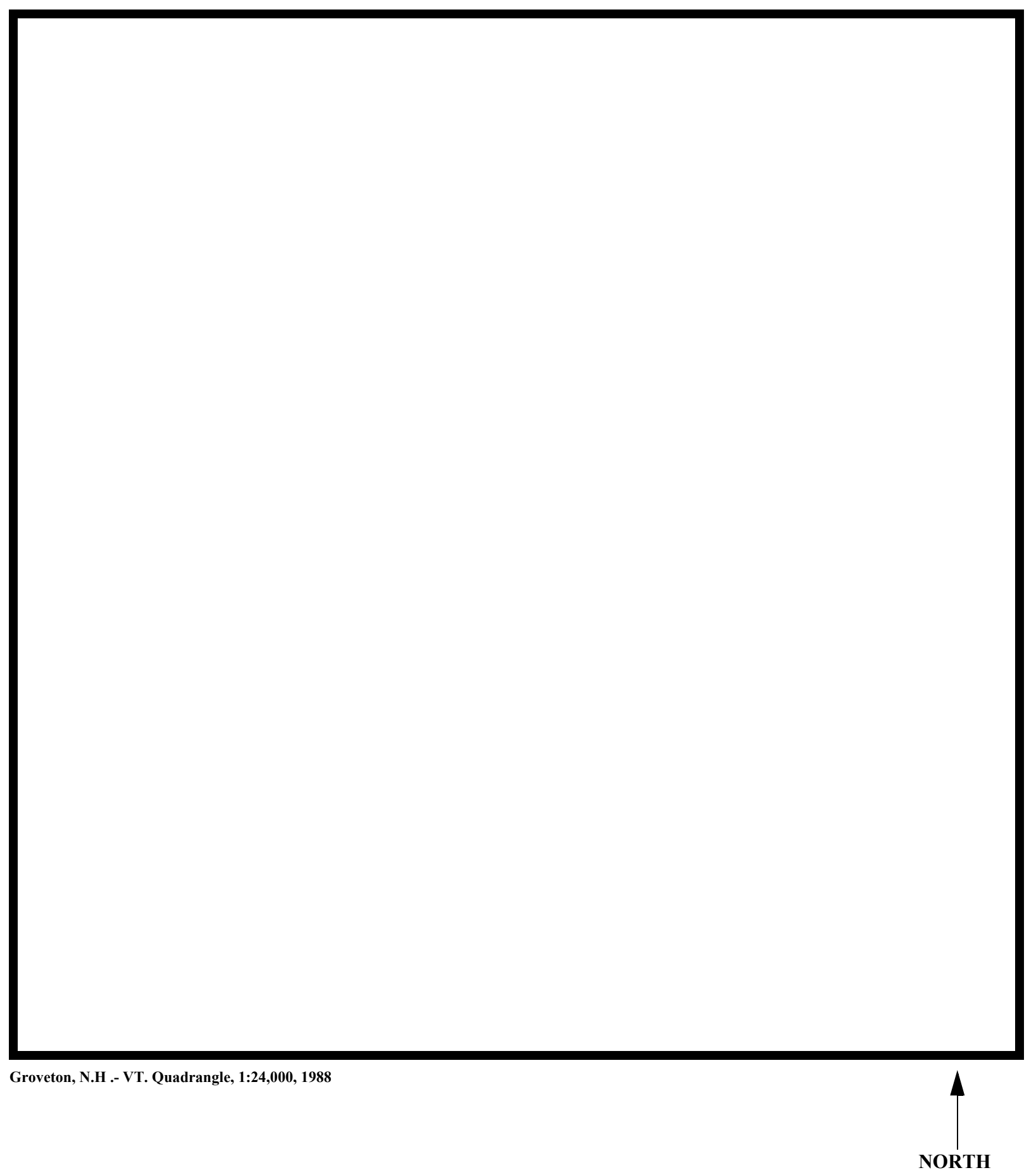

Figure 1. Location of study area on USGS 1:24,000 scale map. 
Figure 2. Location of study area on Vermont Agency of Transportation town highway map. 

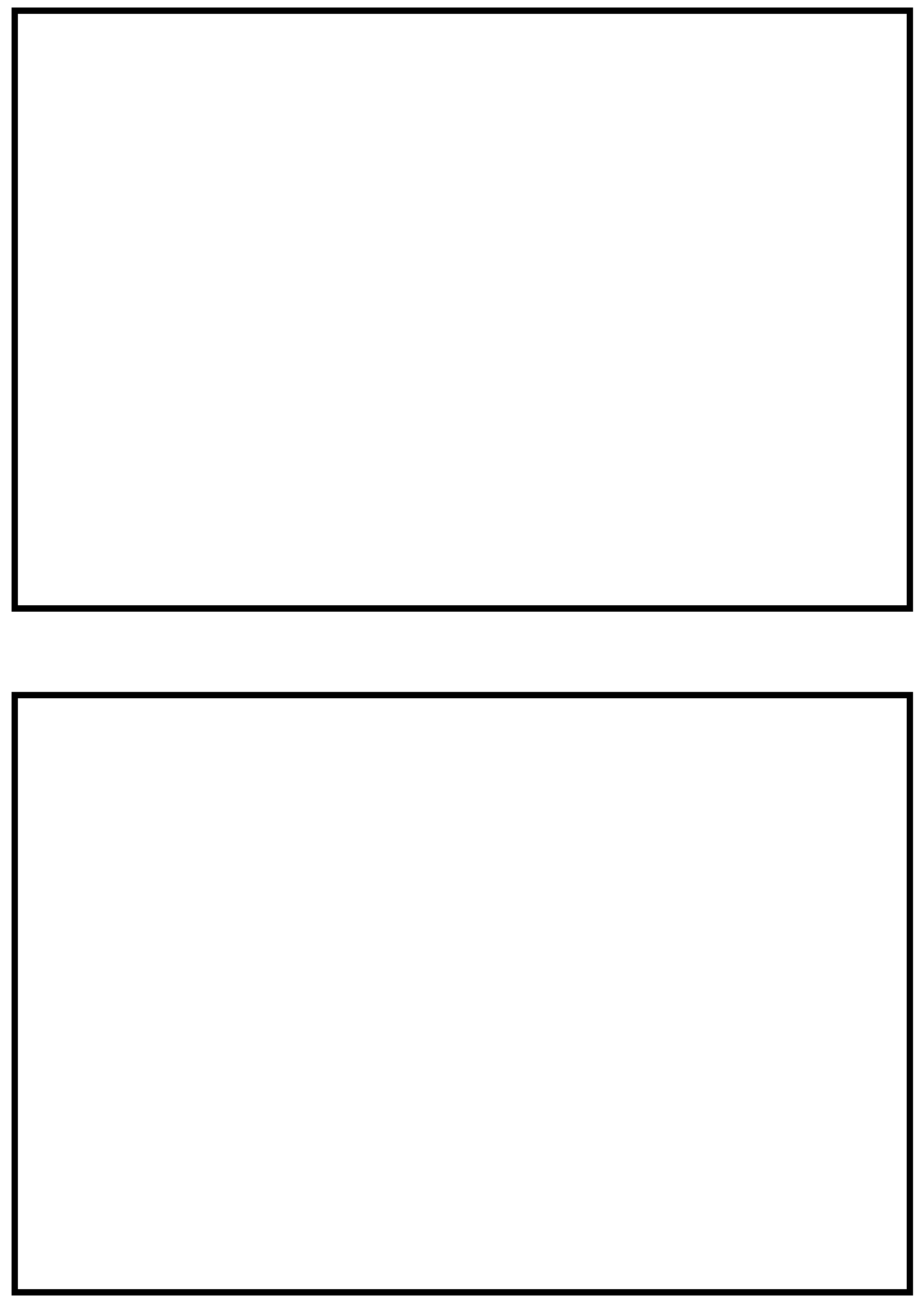

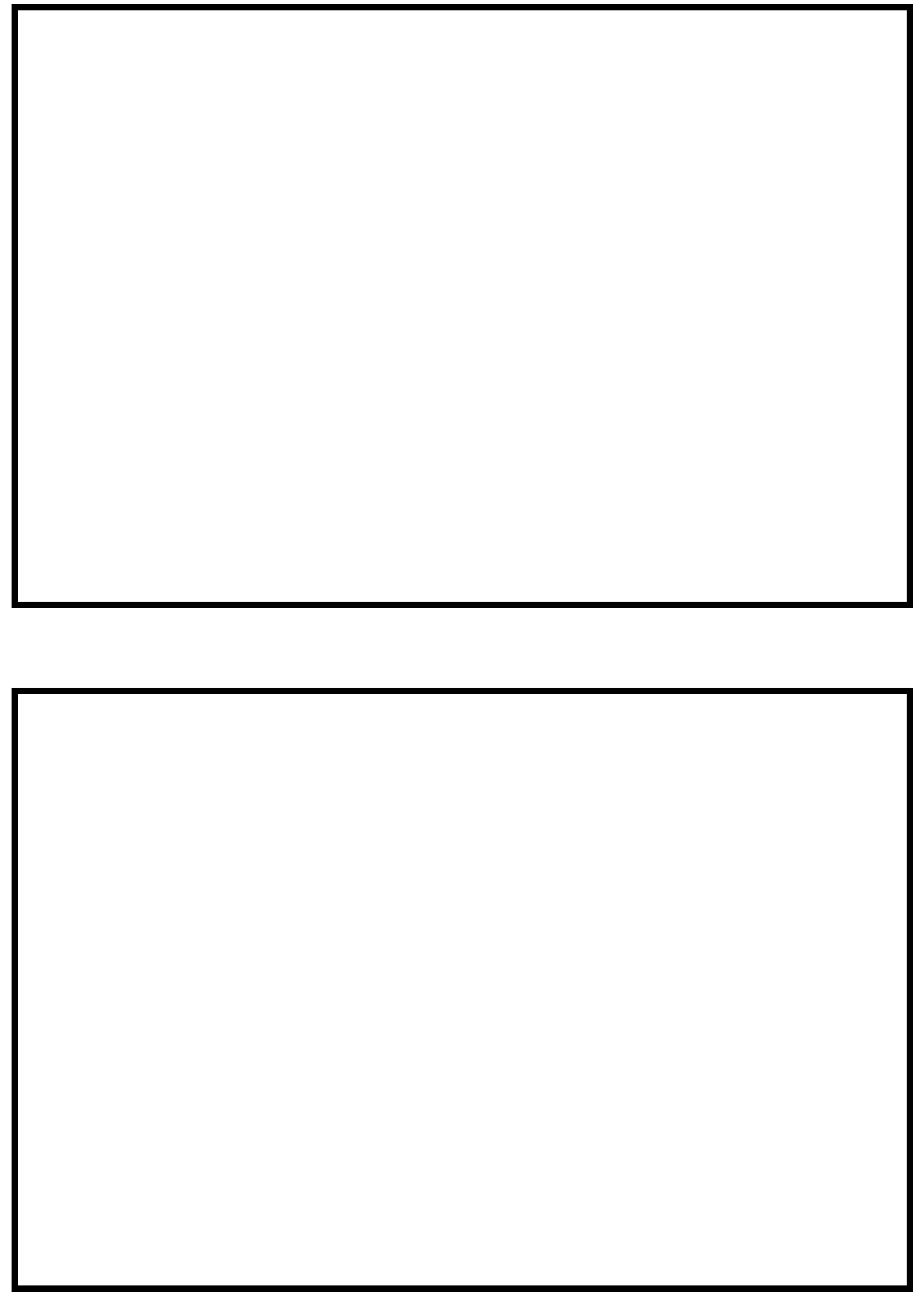


\section{LEVEL II SUMMARY}

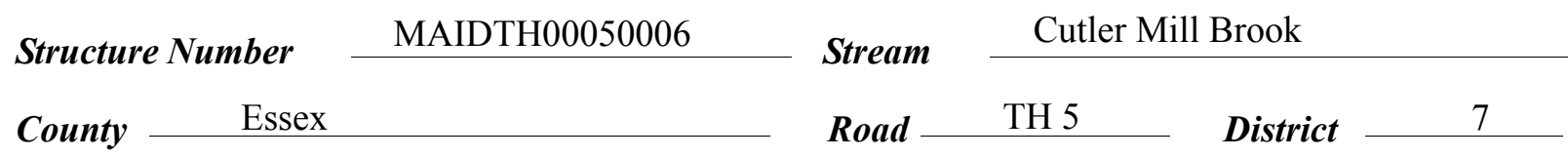

\section{Description of Bridge}

Bridge length $\stackrel{25}{2} \boldsymbol{f t} \quad$ Bridge width $\frac{17.2}{f t}$ Max span length $\stackrel{23}{f t}$ Alignment of bridge to road (on curve or straight)

Abutment type Vertical, concrete

Stone fill on abutment?

$$
\text { Yes }
$$

\section{Embankment type} Curve

Drto of incnortion Type-3, along the entire base length of the upstream left and right
Dasnomintin.. of atan s f:ll wingwalls, left and right abutments, downstream left wingwall, and at the DS end of the downstream right wingwall.

Abutments and wingwalls are concrete.

$\cdots$

\section{Yes}

\section{Is bridge skewed to flood flow according to Yes ' survey? Angle}

35

There is a moderate bend noted in the upstream reach. However, the stream is noted as straight in the immediate vicinity of the bridge.

Debris accumulation on bridge at time of Level I or Level II site visit:

$$
\begin{gathered}
\text { Date of insnortion } \\
7 / 13 / 95 \\
\hline
\end{gathered}
$$

Level I

$$
7 / 13 / 95
$$

\section{Percent of nhannal blocked nortzontatly}

0

\section{Percent of an n....el blocked verticatty}

0

Level II

Moderate due to bend in the channel and angle of bridge opening. The historical data form indicates ice build-up problems have occurred at the site in the past.

Potential for debris

None.were observed on 7/13/96.

Doscriho anv, fonturos noar ar at tho hridoo that mav, affort flou, (includo ahsorvation dato) 


\section{Description of the Geomorphic Setting}

General topography The channel is located within a moderate relief valley with a flat to slightly irregular flood plain and steep valley wall on the right.

Geomorphic conditions at bridge site: downstream (DS), upstream (US)

Date of inspection $\quad 7 / 13 / 95$

DS left: $\quad$ Moderately sloping channel bank to narrow flood plain/wetland

DS right: $\quad$ Moderately sloping channel bank to irregular overbank

US left: $\quad$ Moderately sloping channel bank to narrow flood plain/wetland

US right: $\quad$ Steep channel bank to moderately sloping overbank

\section{Description of the Channel}

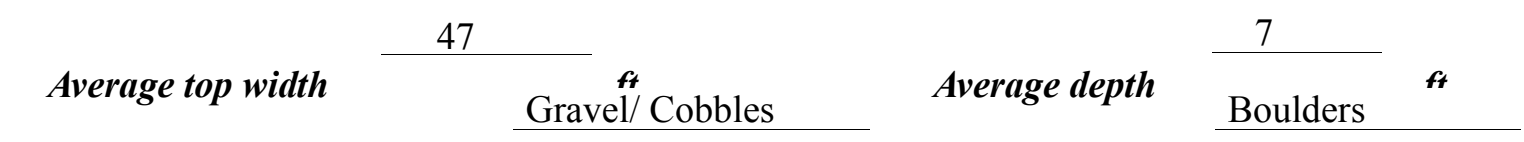

Predominant bed material

Bank material Straight and stable

with semi-allúvial channel boundaries.

$7 / 13 / 95$

Vegetative co 1 Trees and brush

DS left: $\quad$ Tree and brush

DS right: $\quad$ Grass and brush, with trees on the immediate banks more than $50 \mathrm{ft}$ US

US left: $\quad$ Brush, grass, and a few trees

US right: $\quad$ Yes

Do banks appear stable? -

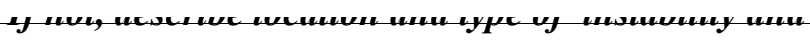

date of observatton.

None observed on

7/13/95.

Describe any obstructions in channel and date of observation. 


\title{
Hydrology
}

Drainage area $\frac{14.7}{m^{2}}{ }^{2}$

Percentage of drainage area in physiographic provinces: (approximate)

Physiographic province/section

New England/White Mountain
Percent of drainage area 100

\begin{abstract}
Is drainage area considered rural or urban?
Rural urbanization:

Describe any significant
\end{abstract}

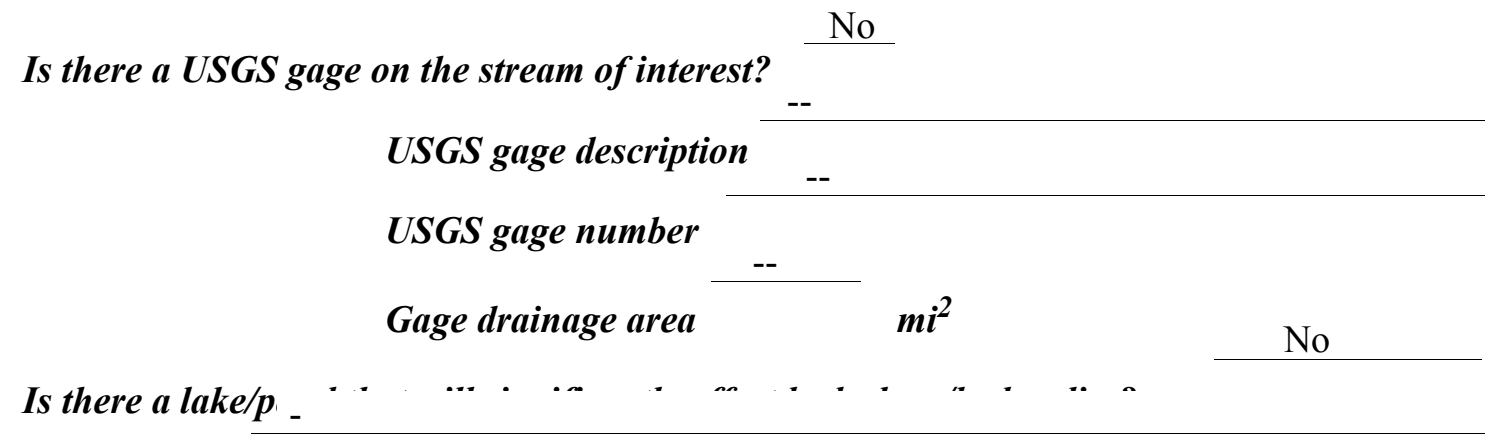

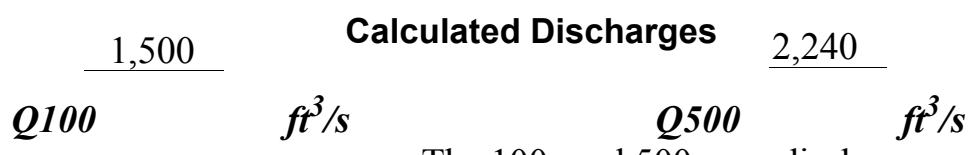

The 100- and 500-year discharges are flood

frequency estimates available from the VTAOT database (written communication, May 1995)

for this bridge. The values used were within a range defined by flood frequency curves developed from several empirical methods (Benson, 1962; Johnson and Tasker, 1974; FHWA, 1983; Potter, 1957a\&b; Talbot, 1887). Each curve was extended graphically to the 500-year discharge. 


\section{Description of the Water-Surface Profile Model (WSPRO) Analysis}

Datum for WSPRO analysis (USGS survey, sea level, VTAOT plans)

Sea Level

Datum tie between USGS survey and VTAOT plans

Sea level (NGVD) was used as

the datum for the USGS survey and the VTAOT plans.

Description of reference marks used to determine USGS datum. $\quad$ RM1 is VTAOT

BM \# 3, a spike near the base of a 12 inch Spruce tree, $50 \mathrm{ft}$ left of the left abutment on TH5 and $10 \mathrm{ft}$ off the downstream side of the road (elev. $1005.41 \mathrm{ft}$, NGVD). RM2 is VTAOT BM\#4, a

spike in the root of an 18 inch balsom tree, $80 \mathrm{ft}$ right of the right abutment on TH5 and $30 \mathrm{ft}$ off the downstream side of the road (elev. $1015.94 \mathrm{ft}$, NGVD).

\section{Cross-Sections Used in WSPRO Analysis}

\begin{tabular}{cccl}
\hline${ }^{1}$ Cross-section & $\begin{array}{c}\text { Section } \\
\text { Reference } \\
\text { Distance } \\
\text { (SRD) in feet }\end{array}$ & $\begin{array}{c}{ }^{2} \text { Cross-section } \\
\text { development }\end{array}$ & \multicolumn{1}{c}{ Comments } \\
\hline EXIT1 & -20 & 1 & Exit section \\
FULLV & 0 & 2 & $\begin{array}{l}\text { Downstream Full-valley } \\
\text { section (Templated from } \\
\text { EXIT1) }\end{array}$ \\
BRIDG & 0 & 1 & $\begin{array}{l}\text { Bridge section } \\
\text { RDWAY }\end{array}$ \\
APPRO & 12 & 1 & $\begin{array}{l}\text { Moad Grade section } \\
\text { Modelled Approach sec- } \\
\text { tion (Templated from } \\
\text { APTEM) }\end{array}$ \\
APTEM & 44 & 2 & $\begin{array}{l}\text { Approach section as sur- } \\
\text { veyed (Used as a tem- } \\
\text { plate) }\end{array}$ \\
\hline
\end{tabular}

${ }^{1}$ For location of cross-sections see plan-view sketch included with Level I field form, Appendix E. 


\section{Data and Assumptions Used in WSPRO Model}

Hydraulic analyses of the reach were done by use of the Federal Highway Administration's WSPRO step-backwater computer program (Shearman and others, 1986, and Shearman, 1990). The analyses reported herein reflect conditions existing at the site at the time of the study. Furthermore, in the development of the model it was necessary to assume no accumulation of debris or ice at the site. Results of the hydraulic model are presented in the Bridge Hydraulic Summary, appendix B, and figure 7.

Channel roughness factors (Manning's " $n$ ") used in the hydraulic model were estimated using field inspections at each cross section following the general guidelines described by Arcement and Schneider (1989). Final adjustments to the values were made during the modelling of the reach. Channel " $n$ " values for the reach ranged from 0.040 to 0.050 , and overbank " $n$ " values ranged from 0.050 to 0.110 .

Normal depth at the exit section (EXIT1) was assumed as the starting water surface. This depth was computed by use of the slope-conveyance method outlined in the user's manual for WSPRO (Shearman, 1990). The slope used was $0.0143 \mathrm{ft} / \mathrm{ft}$, which was estimated from the appropriate topographic map (U.S. Geological Survey, 1988).

The surveyed approach section (APTEM) was moved along the approach channel slope $(0.0148 \mathrm{ft} / \mathrm{ft})$ to establish the modelled approach section (APPRO), one bridge length upstream of the upstream face as recommended by Shearman and others (1986). This location provides a consistent method for determining scour variables.

A portion of the flow is diverted away from this bridge when the water surface overtops the left road approach. The water flows down Town Highway 4 and along the road embankment, returning to the main channel downstream of this site. Thus, a split-flow analysis was performed to determine the discharge diverted around the bridge. The 100- and 500-year discharges were reduced by the diverted discharges to model the hydraulics at the bridge.

For the 100-year and incipient-overtopping discharge, WSPRO assumes critical depth at the

bridge section. Supercritical models were developed for these discharges. Analyzing both the supercritical and subcritical profiles for each discharge, it can be determined that the water surface profile does pass through critical depth within the bridge opening. Thus, the assumptions of critical depth at the bridge are satisfactory solutions. 


\section{Bridge Hydraulics Summary}

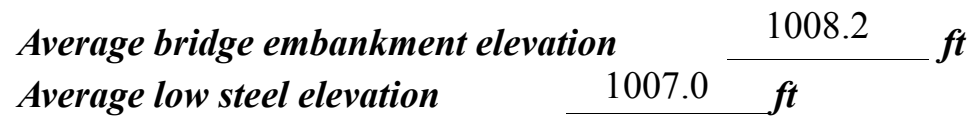

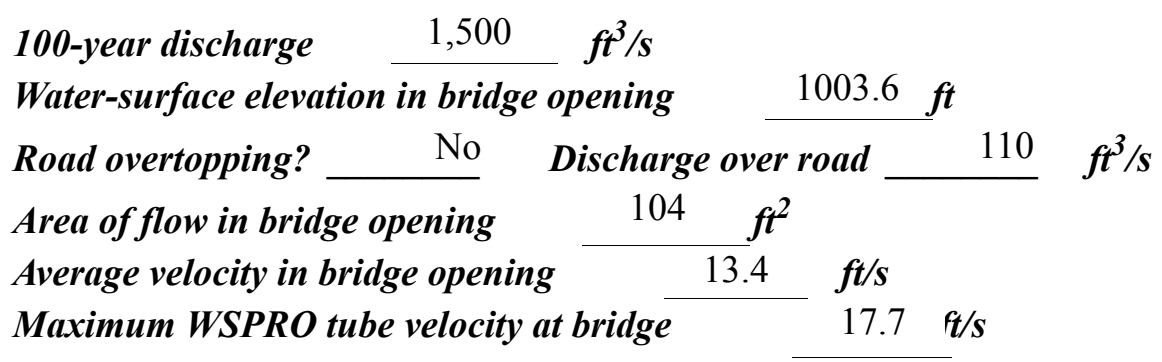

Water-surface elevation at Approach section with bridge

Water-surface elevation at Approach section without bridge

1006.9

Amount of backwater caused by bridge

$$
3.2 \text { it }
$$

500-year discharge $\quad 2,240 \quad \mathrm{ft}^{3} / \mathrm{s}$

Water-surface elevation in bridge opening

$1007.2 \mathrm{ft}$

$\begin{array}{llllll}\text { Road overtopping? ___ Yes Discharge over road ___ } & 925 & \mathrm{ft}^{3} / \mathrm{s}\end{array}$

Area of flow in bridge opening

Average velocity in bridge opening 168

Maximum WSPRO tube velocity at bridge 7.8

$7.8 \mathrm{ft} / \mathrm{s}$
$11.6 \quad \mathrm{~s}$

Water-surface elevation at Approach section with bridge

Water-surface elevation at Approach section without bridge

1008.2

Amount of backwater caused by bridge 4.2 ,t

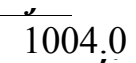

Incipient overtopping discharge $\quad 1,310 \mathrm{ft}^{3} / \mathrm{s}$

Water-surface elevation in bridge opening $1003.3 \mathrm{t}$

Area of flow in bridge opening $\quad 100 \quad \mathrm{ft}^{2}$

Average velocity in bridge opening $\quad 13.1 \mathrm{ft} / \mathrm{s}$

Maximum WSPRO tube velocity at bridge $\quad 17.2 \mathrm{ft} / \mathrm{s}$

Water-surface elevation at Approach section with bridge

Water-surface elevation at Approach section without bridge Amount of backwater caused by bridge 2.9 , $t$ 


\section{Scour Analysis Summary}

\section{Special Conditions or Assumptions Made in Scour Analysis}

Scour depths were computed using the general guidelines described in Hydraulic Engineering Circular 18 (Richardson and Davis, 1995). Scour depths were calculated assuming an infinite depth of erosive material and a homogeneous particle-size distribution. The results of the scour analyses for the 100- and 500-year discharges are presented in tables 1 and 2. Scour depths are shown graphically in figure 8 for the 100-year discharge. Total scour depths computed for the 500-year discharge were less than those for the 100-year discharge and therefore do not appear in figure 8.

Contraction scour for the 100-year and incipient roadway-overtopping discharges was computed by use of the Laursen clear-water contraction scour equation (Richardson and Davis, 1995, p. 32, equation 20). At this site, the 500-year discharge resulted in unsubmerged orifice flow. Contraction scour at bridges with orifice flow is best estimated by use of the Chang pressure-flow scour equation (oral communication, J. Sterling Jones, October 4,1996$)$. Thus, contraction scour for the 500 -year discharge was computed by use of the Chang equation (Richardson and Davis, 1995, p. 145-146). The streambed armoring depths computed suggest that armoring will not limit the depth of contraction scour.

For comparison, contraction scour for the 500-year discharge also was computed by use of the Laursen clear-water contraction scour equation and the Umbrell pressure-flow equation (Richardson and Davis, 1995, p. 144). Furthermore, contraction scour was computed by substituting an estimate for the depth of flow at the downstream bridge face in the contraction scour equations for the 500-year discharge. Results with respect to these alternative computations are provided in appendix $\mathrm{F}$.

Abutment scour was computed by use of the Froehlich equation (Richardson and Davis, 1995, p. 48, equation 28). Variables for the Froehlich equation include the Froude number of the flow approaching the embankments, the length of the embankment blocking flow, and the depth of flow approaching the embankment less any roadway overtopping. 


\section{Scour Results}

Contraction scour:

Main channel

Live-bed scour

Clear-water scour

Depth to armoring

Left overbank

Right overbank

Local scour:

Abutment scour

Left abutment

Right abutment

Pier scour

Pier 1

Pier 2

Pier 3

100-year
discharge 500-year discharge

(Scour depths in feet)
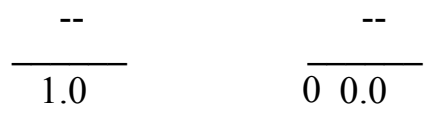

$$
23.8^{-}
$$
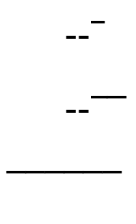


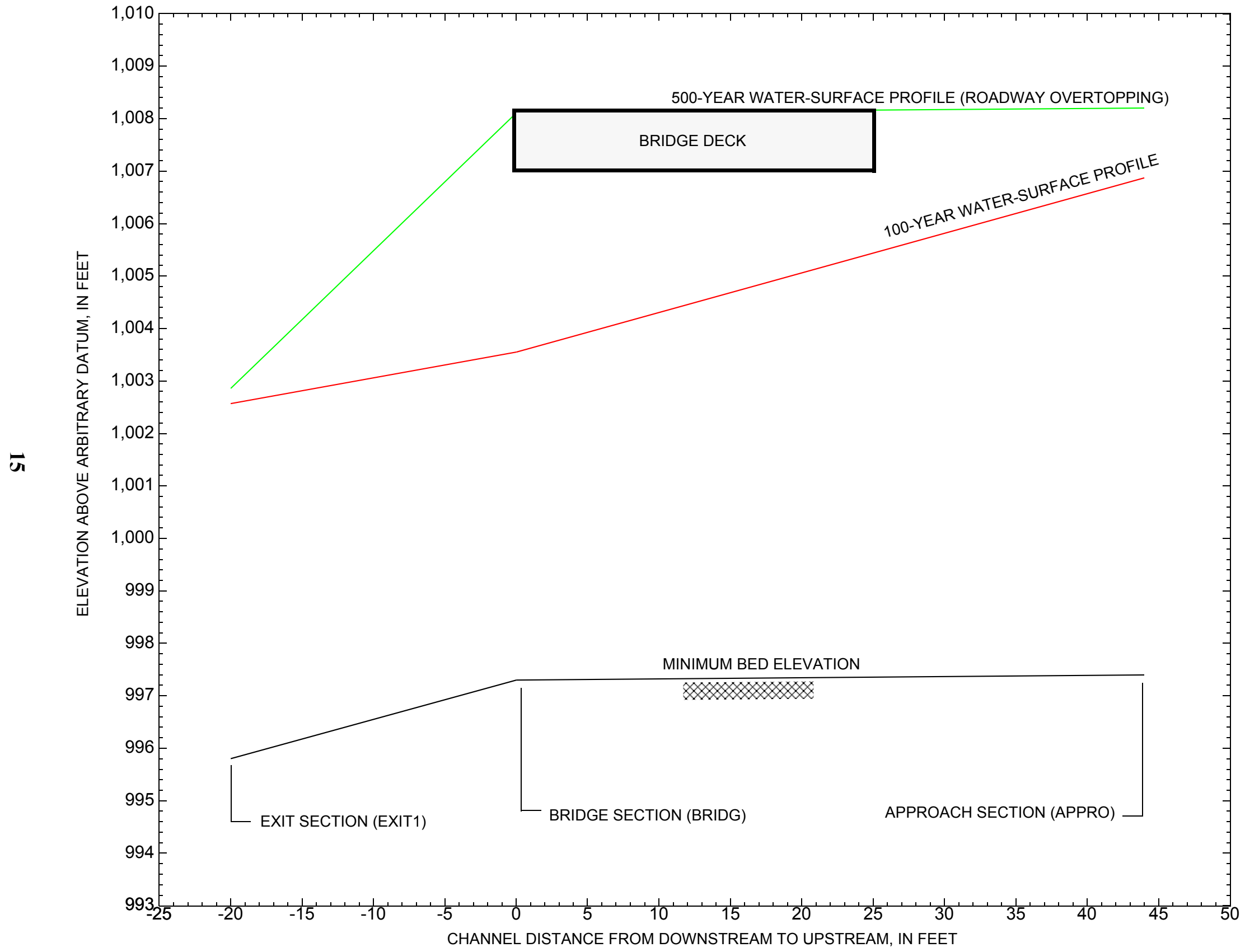

Figure 7. Water-surface profiles for the 100- and 500-year discharges at structure MAIDTH00050006 on Town Highway 5, crossing Cutler Mill Brook, Maidstone, Vermont. 


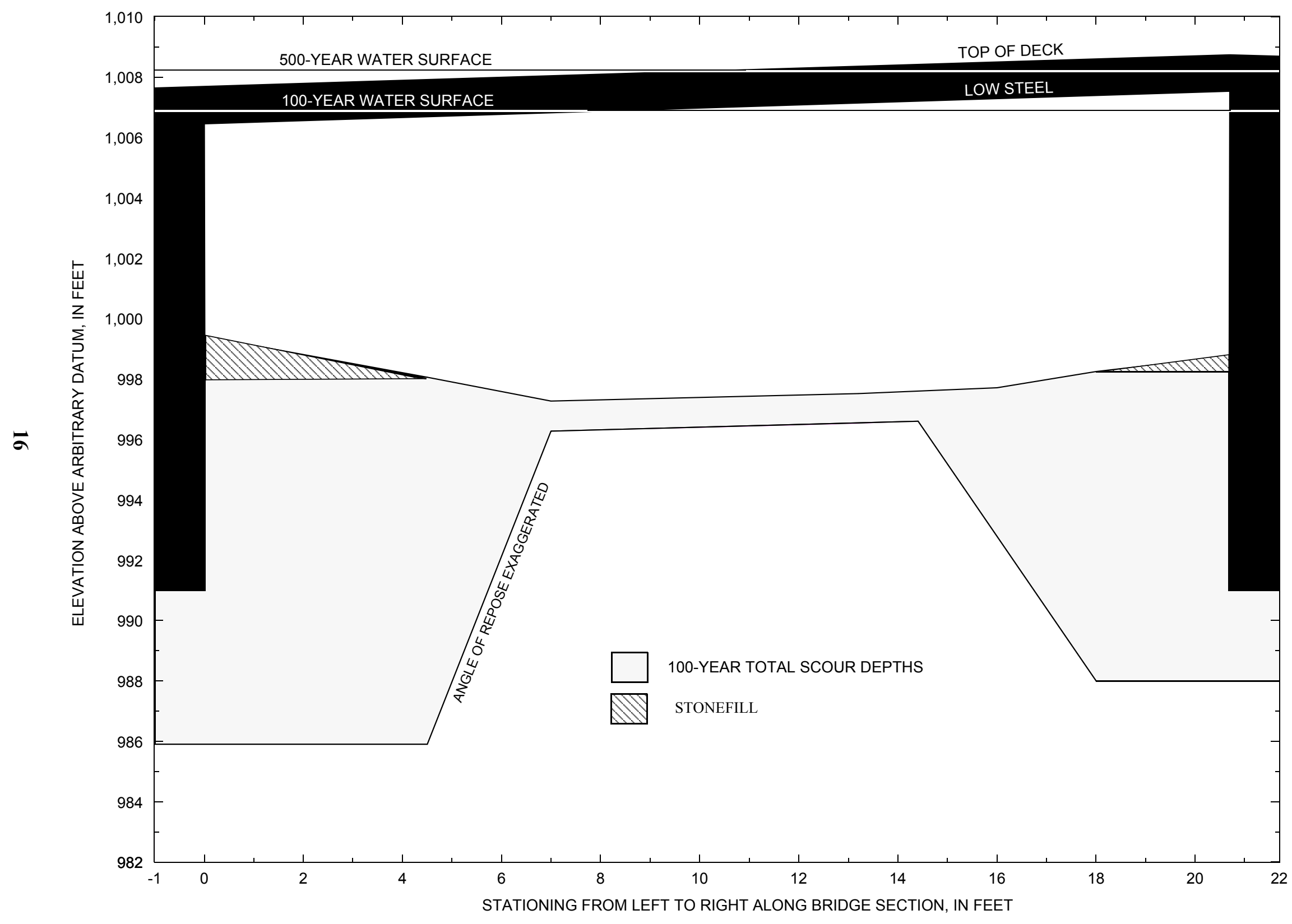

Figure 8. Scour elevations for the 100-year discharge at structure MAIDTH00050006 on Town Highway 5, crossing Cutler Mill Brook, Maidstone, Vermont. 
Table 1. Remaining footing/pile depth at abutments for the 100-year discharge at structure MAIDTH00050006 on Town Highway 5, crossing Cutler Mill Brook, Maidstone, Vermont.

[VTAOT, Vermont Agency of Transportation; --, no data]

\begin{tabular}{|c|c|c|c|c|c|c|c|c|c|c|c|}
\hline Description & Station $^{1}$ & $\begin{array}{l}\text { VTAOT } \\
\text { minimum } \\
\text { low-chord } \\
\text { elevation } \\
\text { (feet) }\end{array}$ & $\begin{array}{l}\text { Surveyed } \\
\text { minimum } \\
\text { low-chord } \\
\text { elevation }{ }^{2} \\
\text { (feet) }\end{array}$ & $\begin{array}{c}\text { Bottom of } \\
\text { footing/pile } \\
\text { elevation }{ }^{2} \\
\text { (feet) }\end{array}$ & $\begin{array}{c}\text { Channel } \\
\text { elevation at } \\
\text { abutment/ } \\
\text { pier }^{2} \\
\text { (feet) }\end{array}$ & $\begin{array}{l}\text { Contraction } \\
\text { scour depth } \\
\text { (feet) }\end{array}$ & $\begin{array}{l}\text { Abutment } \\
\text { scour } \\
\text { depth } \\
\text { (feet) }\end{array}$ & $\begin{array}{l}\text { Pier } \\
\text { scour } \\
\text { depth } \\
\text { (feet) }\end{array}$ & $\begin{array}{l}\text { Depth of } \\
\text { total scour } \\
\text { (feet) }\end{array}$ & $\begin{array}{c}\text { Elevation of } \\
\text { scour }^{2} \\
\text { (feet) }\end{array}$ & $\begin{array}{c}\text { Remaining } \\
\text { footing/pile } \\
\text { depth } \\
\text { (feet) }\end{array}$ \\
\hline \multicolumn{12}{|c|}{100 -year discharge is 1,500 cubic-feet per second } \\
\hline Left abutment & 0.0 & -- & 1006.5 & 991.0 & 998.1 & 1.0 & 11.2 & -- & 12.2 & 985.9 & -5.1 \\
\hline Right abutment & 20.7 & -- & 1007.5 & 991.0 & 998.3 & 1.0 & 9.3 & -- & 10.3 & 988.0 & -3.0 \\
\hline
\end{tabular}

1.Measured along the face of the most constricting side of the bridge.

2.Arbitrary datum for this study.

Table 2. Remaining footing/pile depth at abutments for the 500-year discharge at structure MAIDTH00050006 on Town Highway 5, crossing Cutler Mill Brook, Maidstone, Vermont.

[VTAOT, Vermont Agency of Transportation; --, no data]

\begin{tabular}{|c|c|c|c|c|c|c|c|c|c|c|c|}
\hline Description & Station $^{1}$ & $\begin{array}{l}\text { VTAOT } \\
\text { minimum } \\
\text { low-chord } \\
\text { elevation } \\
\text { (feet) }\end{array}$ & $\begin{array}{l}\text { Surveyed } \\
\text { minimum } \\
\text { low-chord } \\
\text { elevation }{ }^{2} \\
\text { (feet) }\end{array}$ & $\begin{array}{c}\text { Bottom of } \\
\text { footing/pile } \\
\text { elevation } \\
\text { (feet) }\end{array}$ & $\begin{array}{c}\text { Channel } \\
\text { elevation at } \\
\text { abutment/ } \\
\text { pier }^{2} \\
\text { (feet) }\end{array}$ & $\begin{array}{l}\text { Contraction } \\
\text { scour depth } \\
\text { (feet) }\end{array}$ & $\begin{array}{l}\text { Abutment } \\
\text { scour } \\
\text { depth } \\
\text { (feet) }\end{array}$ & $\begin{array}{l}\text { Pier } \\
\text { scour } \\
\text { depth } \\
\text { (feet) }\end{array}$ & $\begin{array}{l}\text { Depth of } \\
\text { total scour } \\
\text { (feet) }\end{array}$ & $\begin{array}{c}\text { Elevation of } \\
\text { scour }^{2} \\
\text { (feet) }\end{array}$ & $\begin{array}{c}\text { Remaining } \\
\text { footing/pile } \\
\text { depth } \\
\text { (feet) }\end{array}$ \\
\hline \multicolumn{12}{|c|}{500 -year discharge is 2,240 cubic-feet per second } \\
\hline Left abutment & 0.0 & -- & 1006.5 & 991.0 & 998.1 & 0.0 & 11.4 & -- & 11.4 & 986.7 & -4.3 \\
\hline Right abutment & 20.7 & -- & 1007.5 & 991.0 & 998.3 & 0.0 & 7.7 & -- & 7.7 & 990.6 & -0.4 \\
\hline
\end{tabular}

1.Measured along the face of the most constricting side of the bridge.

2.Arbitrary datum for this study. 


\section{SELECTED REFERENCES}

Arcement, G.J., Jr., and Schneider, V.R., 1989, Guide for selecting Manning's roughness coefficients for natural channels and flood plains: U.S. Geological Survey Water-Supply Paper 2339, 38 p.

Barnes, H.H., Jr., 1967, Roughness characteristics of natural channels: U.S. Geological Survey Water-Supply Paper 1849,213 p.

Benson, M. A., 1962, Factors Influencing the Occurrence of Floods in a Humid Region of Diverse Terrain: U.S. Geological Survey WaterSupply Paper 1580-B, 64 p.

Brown, S.A. and Clyde, E.S., 1989, Design of riprap revetment: Federal Highway Administration Hydraulic Engineering Circular No. 11, Publication FHWA-IP-89-016, 156 p.

Federal Highway Administration, 1983, Runoff estimates for small watersheds and development of sound design: Federal Highway Administration Report FHWA-RD-77-158.

Federal Highway Administration, 1993, Stream Stability and Scour at Highway Bridges: Participant Workbook: Federal Highway Administration Report FHWA-HI-91-011.

Froehlich, D.C., 1989, Local scour at bridge abutments in Ports, M.A., ed., Hydraulic Engineering--Proceedings of the 1989 National Conference on Hydraulic Engineering: New York, American Society of Civil Engineers, p. 13-18.

Hayes, D.C.,1993, Site selection and collection of bridge-scour data in Delaware, Maryland, and Virginia: U.S. Geological Survey WaterResources Investigation Report 93-4017, 23 p.

Interagency Advisory Committee on Water Data, 1982, Guidelines for determining flood flow frequency: U.S. Geological Survey, Bulletin 17B of the Hydrology Subcommittee, 190 p.

Johnson, C.G. and Tasker, G.D.,1974, Progress report on flood magnitude and frequency of Vermont streams: U.S. Geological Survey OpenFile Report 74-130, 37 p.

Lagasse, P.F., Schall, J.D., Johnson, F., Richardson, E.V., Chang, F., 1995, Stream Stability at Highway Structures: Federal Highway Administration Hydraulic Engineering Circular No. 20, Publication FHWA-IP-90-014, 144 p.

Laursen, E.M., 1960, Scour at bridge crossings: Journal of the Hydraulics Division, American Society of Civil Engineers, v. 86, no. HY2, p. 39-53.

Potter, W. D., 1957a, Peak rates of runoff in the Adirondack, White Mountains, and Maine woods area, Bureau of Public Roads

Potter, W. D., 1957b, Peak rates of runoff in the New England Hill and Lowland area, Bureau of Public Roads

Richardson, E.V. and Davis, S.R., 1995, Evaluating scour at bridges: Federal Highway Administration Hydraulic Engineering Circular No. 18, Publication FHWA-IP-90-017, 204 p.

Richardson, E.V., Simons, D.B., and Julien, P.Y., 1990, Highways in the river environment: Federal Highway Administration Publication FHWA-HI-90-016.

Ritter, D.F., 1984, Process Geomorphology: W.C. Brown Co., Debuque, Iowa, 603 p.

Shearman, J.O., 1990, User's manual for WSPRO--a computer model for water surface profile computations: Federal Highway Administration Publication FHWA-IP-89-027, 187 p.

Shearman, J.O., Kirby, W.H., Schneider, V.R., and Flippo, H.N., 1986, Bridge waterways analysis model; research report: Federal Highway Administration Publication FHWA-RD-86-108, 112 p.

Talbot, A.N., 1887, The determination of water-way for bridges and culverts.

U.S. Geological Survey, 1988, Groveton, NH-VT 7.5 Minute Series quadrangle map: U.S. Geological Survey Topographic Maps, Scale $1: 24,000$. 


\section{APPENDIX A: \\ WSPRO INPUT FILE}


WSPRO INPUT FILE

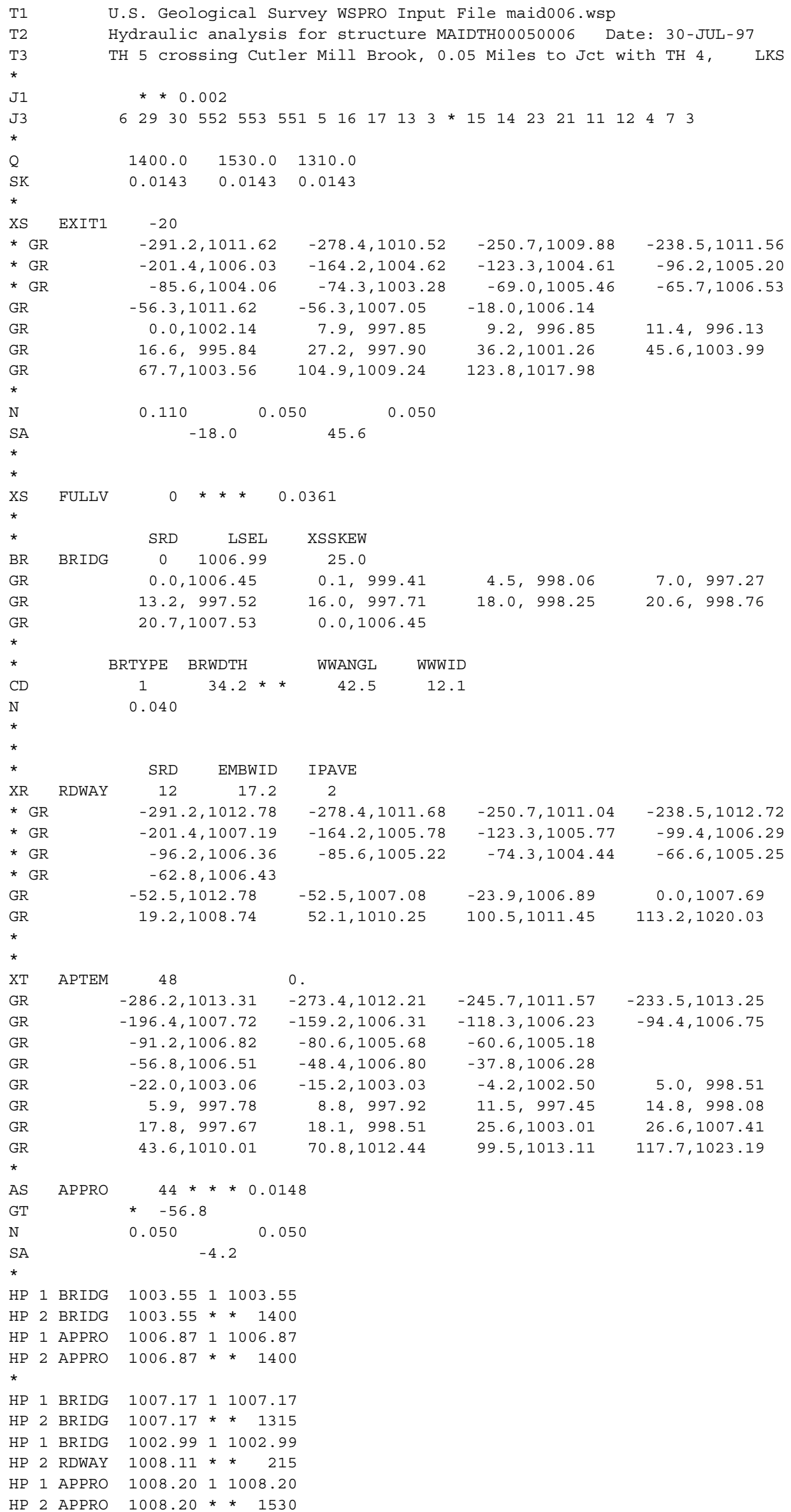




\section{APPENDIX B: \\ WSPRO OUTPUT FILE}


WSPRO OUTPUT FILE

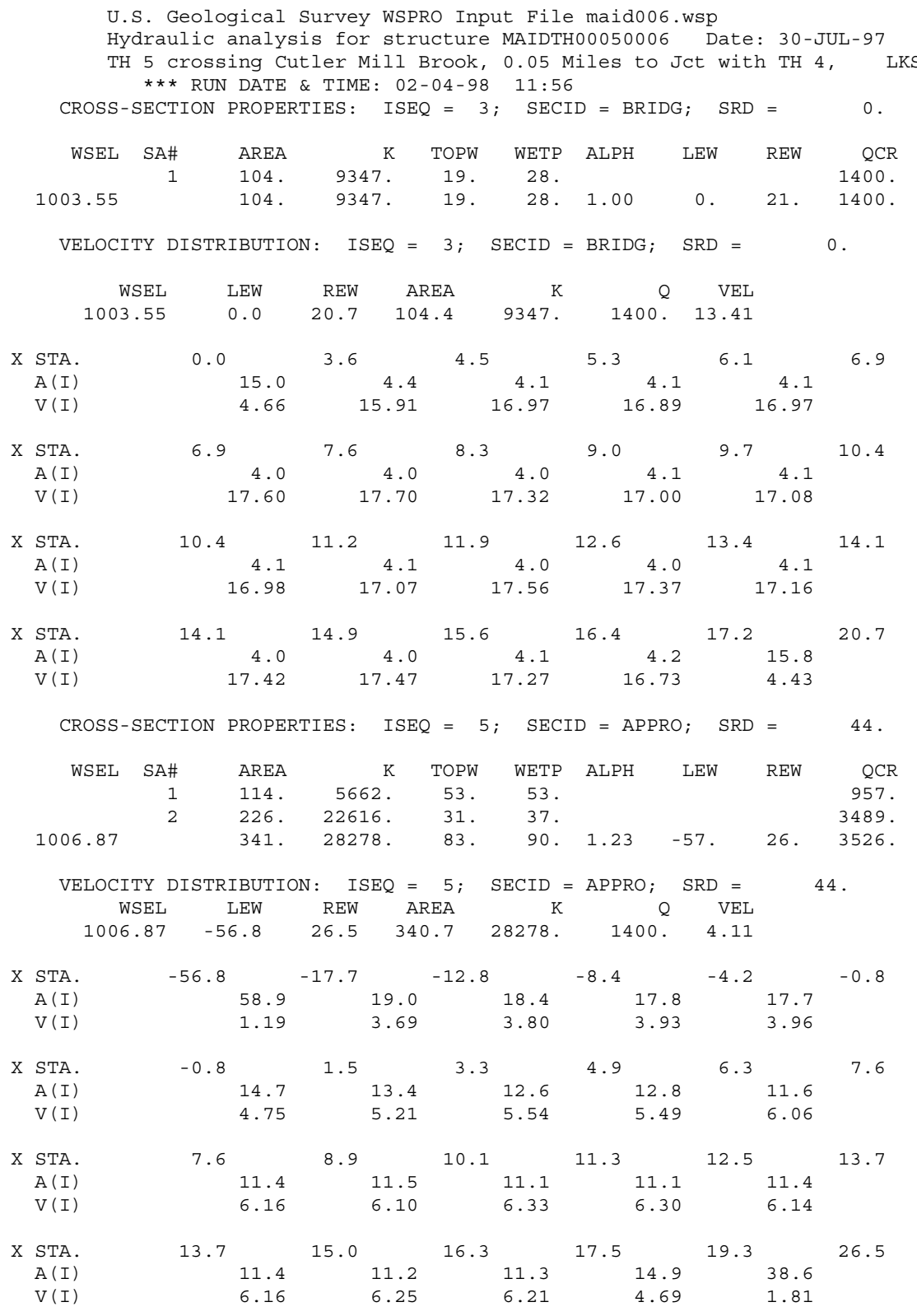




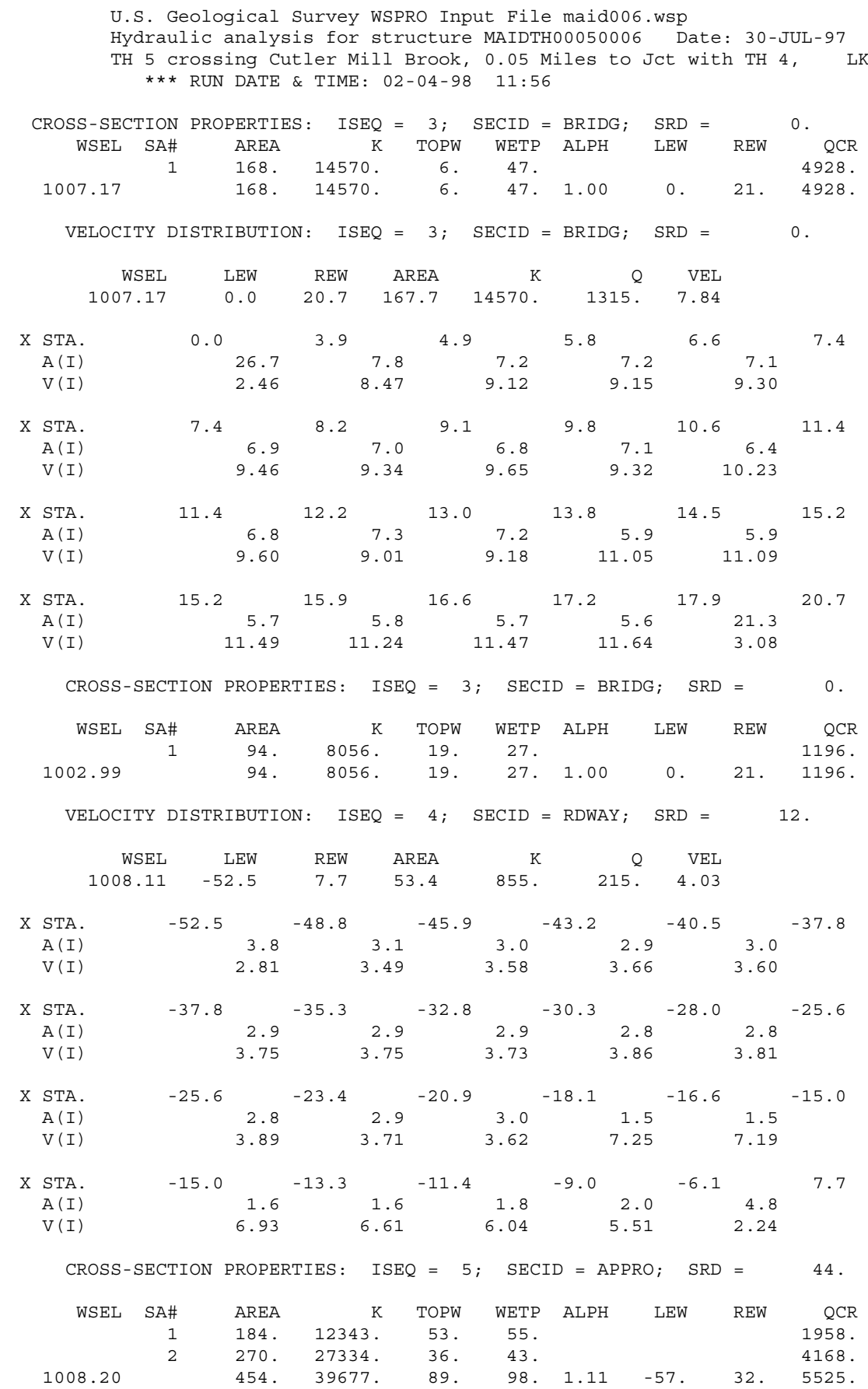

VELOCITY DISTRIBUTION: ISEQ $=5 ; \quad \operatorname{SECID}=\mathrm{APPRO} ; \quad \mathrm{SRD}=4$.

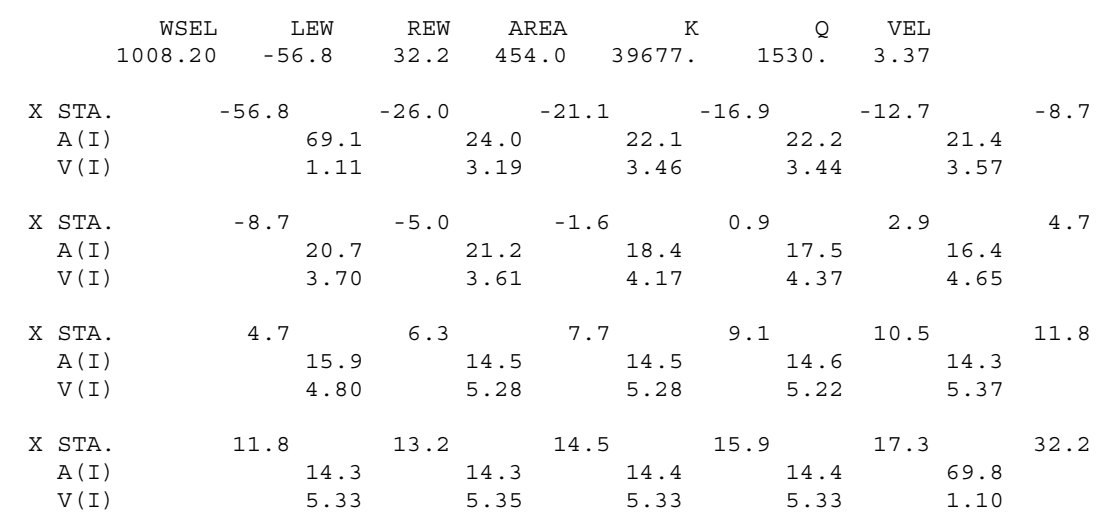


WSPRO OUTPUT FILE (continued)

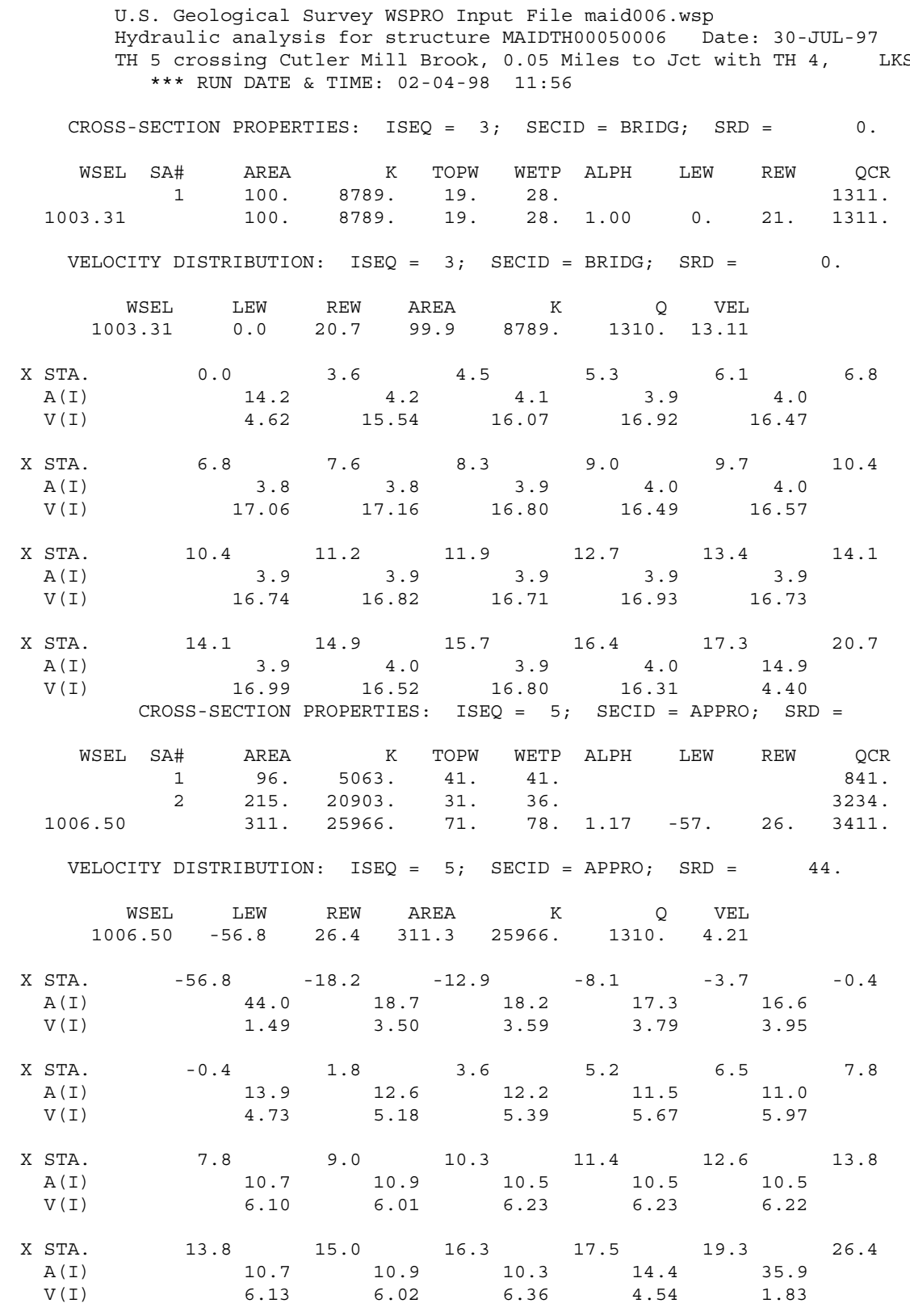


WSPRO OUTPUT FILE (continued)

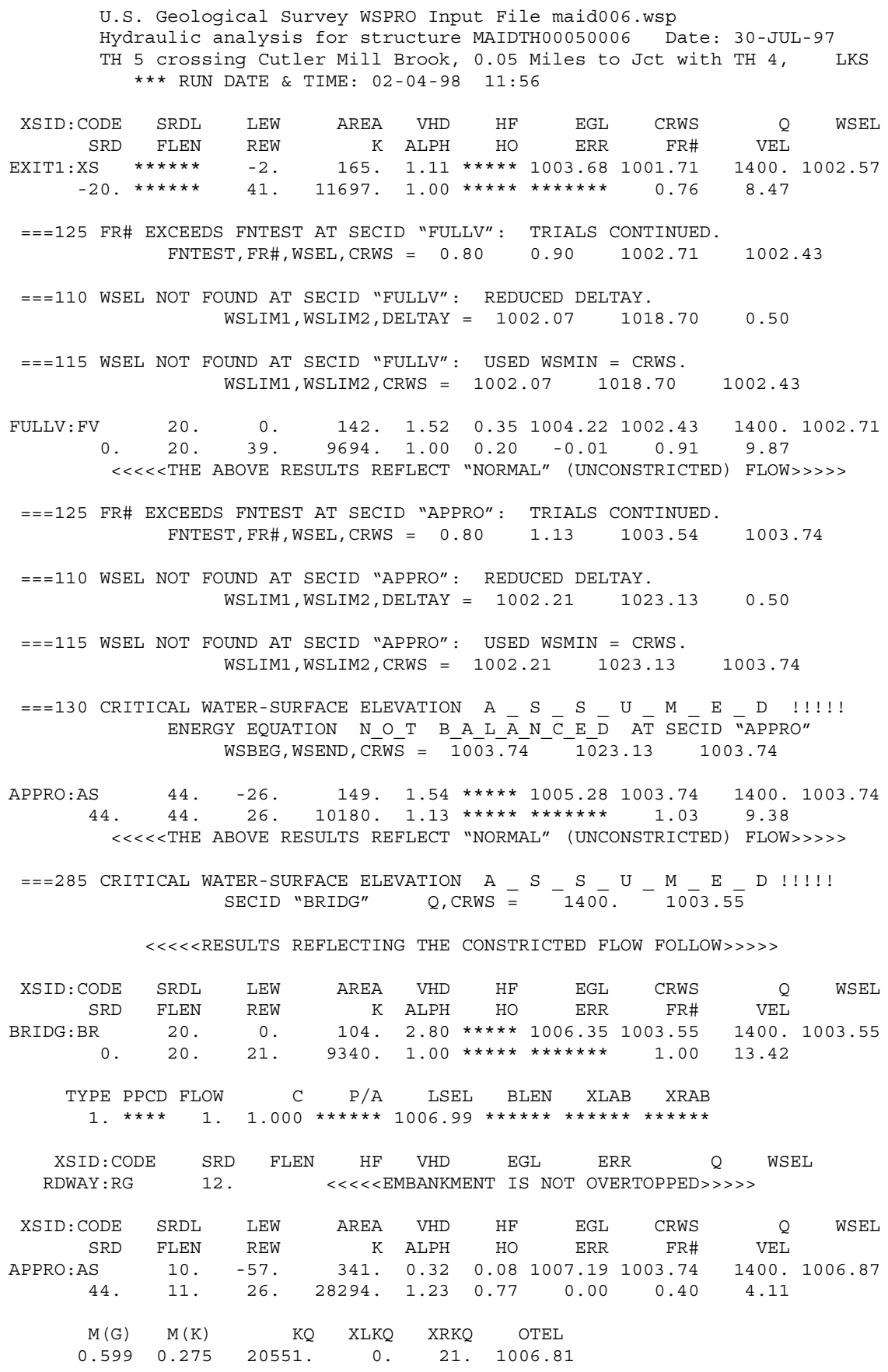

FIRST USER DEFINED TABLE.

\begin{tabular}{|c|c|c|c|c|c|c|c|c|}
\hline XSID : CODE & SRD & LEW & REW & $Q$ & $\mathrm{~K}$ & AREA & VEL & WSEL \\
\hline EXIT1 : XS & -20 & -2 & 41. & 1400 . & 11697. & 165. & 8.47 & 1002.57 \\
\hline FULLV : FV & 0 & 0 & 39. & 1400. & 9694 & 142. & 9.87 & 1002.71 \\
\hline BRIDG : BR & 0 & 0 & 21. & 1400 . & 9340 & 104. & 13.42 & 1003.55 \\
\hline RDWAY : RG & \multicolumn{3}{|c|}{$12 . * \star \star * \star * \star * \star * \star * \star * \star *$} & \multicolumn{3}{|c|}{$0 . * * * * * * * * * * * * * * * * * * *$} & \multirow{2}{*}{\multicolumn{2}{|c|}{$\begin{array}{l}2.00 * * * * * * * * \\
4.11 \quad 1006.87\end{array}$}} \\
\hline APPRO : AS & 44. & -57 & 26. & 1400 . & 28294 . & 341 . & & \\
\hline
\end{tabular}

SECOND USER DEFINED TABLE.

\begin{tabular}{|c|c|c|c|c|c|c|c|c|c|}
\hline XSID : CODE & CRWS & FR\# & YMIN & YMAX & $\mathrm{HF}$ & $\mathrm{HO}$ & VHD & EGL & WSEL \\
\hline EXIT1:XS & 1001.71 & 0.76 & 995.84 & $1017.98 *$ & $\star * * * * *$ & $\star * \star * *$ & 1.11 & 1003.68 & 1002.57 \\
\hline FULLV : FV & 1002.43 & 0.91 & 996.56 & 1018.70 & 0.35 & 0.20 & 1.52 & 1004.22 & 1002.71 \\
\hline BRIDG : BR & 1003.55 & 1.00 & 997.27 & 1007.53 * & $\star \star \star \star \star * *$ & $\star \star \star \star \star *$ & 2.80 & 1006.35 & 1003.55 \\
\hline RDWAY : RG & 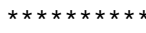 & $\star \star \star \star * *$ & 1006.89 & 1020.03 * & $\star \star \star \star \star \star \star *$ & $\star \star \star \star * \star *$ & $\star \star \star \star \star *$ & 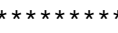 & 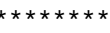 \\
\hline APPRO : AS & 1003.74 & 0.40 & 997.39 & 1023.13 & 0.08 & 0.77 & 0.32 & 1007.19 & 1006.87 \\
\hline
\end{tabular}


WSPRO OUTPUT FILE (continued)

\author{
U.S. Geological Survey WSPRO Input File maido06.wsp \\ Hydraulic analysis for structure MAIDTH00050006 Date: 30-JUL-97 \\ TH 5 crossing Cutler Mill Brook, 0.05 Miles to Jct with TH 4, LKS \\ *** RUN DATE \& TIME: 02-04-98 11:56

\begin{tabular}{|c|c|c|c|c|c|c|c|c|c|}
\hline XSID : CODE & SRDL & LEW & AREA & VHD & $\mathrm{HF}$ & EGL & CRWS & $\mathrm{Q}$ & WSEL \\
\hline SRD & FLEN & REW & K & ALPH & $\mathrm{HO}$ & ERR & FR\# & VEL & \\
\hline EXIT1:XS & $\star \star \star * \star * *$ & -3. & 178. & 1.15 & $\star * \star * * *$ & 1004.01 & 1001.96 & 1530. & 1002.86 \\
\hline-20 & $\star \star \star \star \star \star \star *$ & 42. & 12784 . & 1.00 & 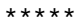 & $\star \star \star \star \star \star \star \star *$ & 0.76 & 8.59 & \\
\hline
\end{tabular} \\ $===125$ FR\# EXCEEDS FNTEST AT SECID "FULLV": TRIALS CONTINUED. \\ FNTEST, FR\#, WSEL, CRWS $=0.80 \quad 0.90 \quad 1003.00 \quad 1002.69$ \\ $===110$ WSEL NOT FOUND AT SECID "FULLV": REDUCED DELTAY

$$
\text { WSLIM1, WSLIM2, DELTAY }=1002.36 \quad 1018.70 \quad 0.50
$$ \\ $==115$ WSEL NOT FOUND AT SECID "FULLV": USED WSMIN = CRWS$$
\text { WSLIM1, WSLIM2, CRWS }=1002.36 \quad 1018.70 \quad 1002.69
$$

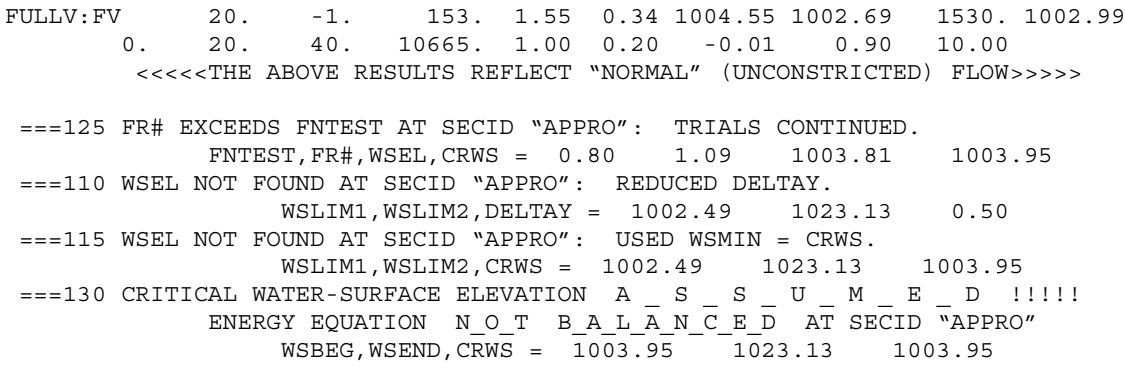

FIRST USER DEFINED TABLE.

\begin{tabular}{|c|c|c|c|c|c|c|c|c|}
\hline XSID : CODE & SRD & LEW & REW & $\mathrm{Q}$ & $\mathrm{K}$ & AREA & VEL & WSEL \\
\hline EXIT1:XS & -20 & -3 & 42. & 1530. & 12784 . & 178. & 8.59 & 1002.86 \\
\hline FULLV : FV & 0. & -1. & 40. & 1530. & 10665. & 153. & 10.00 & 1002.99 \\
\hline BRIDG : BR & 0 . & 0 . & 21. & 1315. & 14559. & 168. & 7.84 & 1007.17 \\
\hline RDWAY : RG & 12. & $\star * * *$ & 215. & 215. & $\star * * * \star *$ & 0 . & 2.00 & 1008.11 \\
\hline APPRO : AS & 44. & -57. & 32 . & 1530. & 39710 . & 454. & 3.37 & 1008.20 \\
\hline
\end{tabular}

SECOND USER DEFINED TABLE.

$\begin{array}{lcrrrrrrrr}\text { XSID : CODE } & \text { CRWS } & \text { FR\# } & \text { YMIN } & \text { YMAX } & \text { HF } & \text { HO } & \text { VHD } & \text { EGL } & \text { WSEL } \\ \text { EXIT1 :XS } & 1001.96 & 0.76 & 995.84 & 1017.98 * * * * * * * * * * * & 1.15 & 1004.01 & 1002.86 \\ \text { FULLV:FV } & 1002.69 & 0.90 & 996.56 & 1018.70 & 0.34 & 0.20 & 1.55 & 1004.55 & 1002.99 \\ \text { BRIDG:BR } & 1003.33 & 0.49 & 997.27 & 1007.53 * * * * * * * * * * & 0.96 & 1008.13 & 1007.17 \\ \text { RDWAY:RG } & * * * * * * * * * * * * * * * & 1006.89 & 1020.03 & 0.04 * * * * * * & 0.20 & 1008.36 & 1008.11 \\ \text { APPRO:AS } & 1003.95 & 0.28 & 997.39 & 1023.13 & 0.04 & 0.77 & 0.20 & 1008.40 & 1008.20\end{array}$


WSPRO OUTPUT FILE (continued)

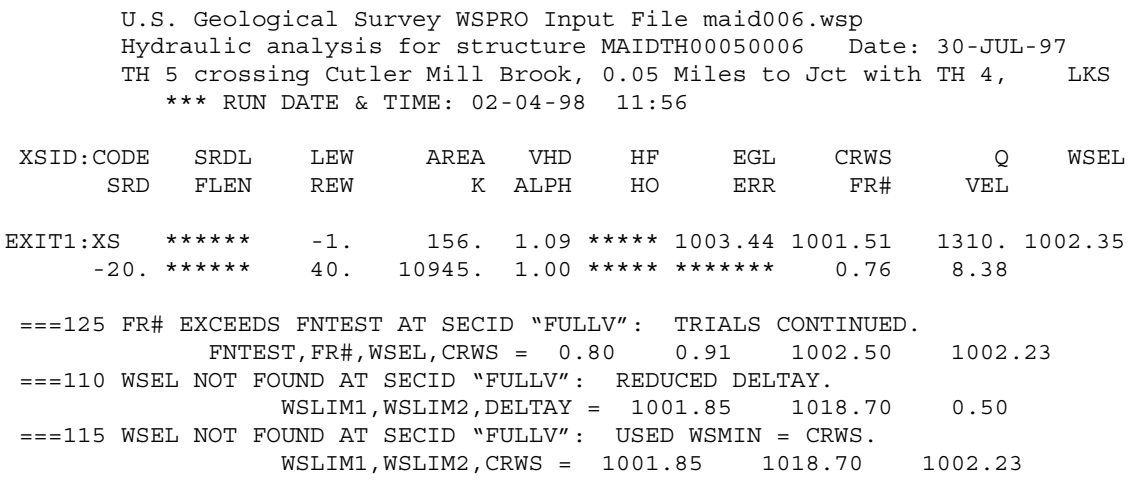

FIRST USER DEFINED TABLE.

\begin{tabular}{|c|c|c|c|c|c|c|c|c|}
\hline XSID : CODE & SRD & LEW & REW & $\mathrm{Q}$ & $\mathrm{K}$ & AREA & VEL & WSEL \\
\hline EXIT1:XS & -20 & -1 & 40 . & 1310. & 10945 . & 156. & 8.38 & 1002.35 \\
\hline FULLV : FV & 0. & 1 . & 38. & 1310. & 8979 . & 134. & 9.79 & 1002.50 \\
\hline BRIDG : BR & 0 & 0 & 21 & 1310. & 8778 & 100. & 13.12 & 1003.31 \\
\hline RDWAY : RG & \multicolumn{3}{|c|}{$12 . * * \star * \star * * * * * * \star \star * * *$} & \multicolumn{3}{|c|}{$0 . * * * * * * * * * * * * * * * * * *$} & 2.00 & 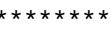 \\
\hline APPRO: AS & 44. & -57 & 26. & 1310. & 25979 . & 312. & 4.20 & 1006.50 \\
\hline XSID : CODE & XLKQ & $\mathrm{XRKQ}$ & & & & & & \\
\hline APPRO : AS & 0. & 21 & 19152 & & & & & \\
\hline
\end{tabular}

SECOND USER DEFINED TABLE.

\begin{tabular}{|c|c|c|c|c|c|c|c|c|c|}
\hline XSID : CODE & CRWS & FR\# & YMIN & YMAX & $\mathrm{HF}$ & $\mathrm{HO}$ & VHD & EGL & WSEL \\
\hline EXIT1:XS & 1001.51 & 0.76 & 995.84 & $1017.98 *$ & $\star * * *$ & $* * *$ & 1.09 & 1003.44 & 1002.35 \\
\hline FULLV : FV & 1002.23 & .91 & 996.56 & 1018.70 & 0.35 & 0.20 & 1.49 & 1003.99 & 1002.50 \\
\hline :BR & 1003.31 & 1.00 & 997.27 & $1007.53 *$ & 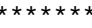 & $\star \star \star \star * *$ & 2.68 & 1005.98 & 1003.31 \\
\hline & 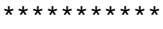 & $* \star \star * *$ & 1006.89 & 1020 . & & & & & \\
\hline : AS & 1003.56 & 0.38 & 997.39 & 1023.13 & 0.08 & 0.76 & 0.32 & 1006.83 & 1006.50 \\
\hline
\end{tabular}




\section{APPENDIX C:}

\section{BED-MATERIAL PARTICLE-SIZE DISTRIBUTION}




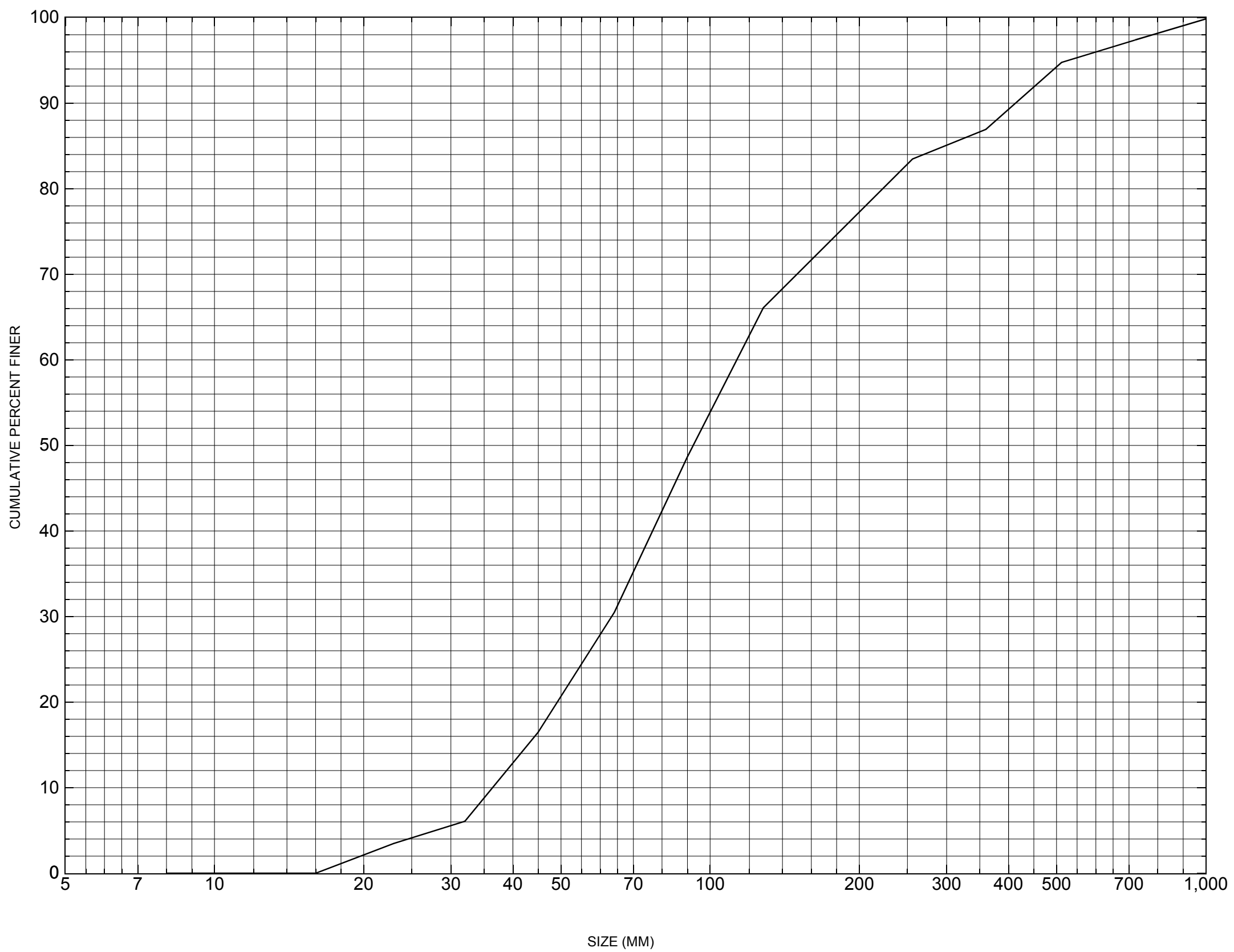

Appendix C. Bed material particle-size distribution for a pebble count in the channel approach of structure MAIDTH00050006, in Maidstone, Vermont. 


\section{APPENDIX D: \\ HISTORICAL DATA FORM}




\section{Structure Number MAIDTH00050006}

\section{General Location Descriptive}

Data collected by (First Initial, Full last name) $\underline{\text { E }}$. BOEHMLER

Date $(M M / D D / Y Y) \_\mathbf{0 8} / \underline{\mathbf{0 5}} / \underline{\mathbf{9 4}}$

Highway District Number (I - 2; nn) 07

Town (FIPS place code; I - 4; nnnnn) $\mathbf{4 2 4 7 5}$

Waterway (I - 6) CUTLER MILL BROOK

Route Number TH005

Topographic Map Groveton, NH

Latitude (I - 16; nnnn.n) 44366
County (FIPS county code; I - 3; nnn)

Mile marker (I - 11; nnn.nnn) $\mathbf{0 0 0 0 0 0}$

Road Name (I - 7): -

Vicinity (I - 9) 0.05 MI JCT TH 5 + TH 4

Hydrologic Unit Code: $\mathbf{0 1 0 8 0 1 0 1}$

Longitude (i - 17; nnnnn.n) 71359

\section{Select Federal Inventory Codes}

FHWA Structure Number (I - 8) $\mathbf{1 0 0 5 1 5 0 0 0 6 0 5 1 5}$

Maintenance responsibility $(I-21 ; n n) \_$03 $\quad$ Maximum span length $(I-48 ; n n n n) \underline{\mathbf{0 0 2 3}}$

Year built (I - 27; YYYY) 1985

Structure length (I - 49; nnnnnn) $\underline{\mathbf{0 0 0 0 2 5}}$

Average daily traffic, ADT (I - 29; nnnnnn) 000010 Deck Width (I- 52; nn.n) 172

Year of ADT (I - 30; YY) $\mathbf{9 2}$

Channel \& Protection $(I-61 ; n) \underline{7}$

Opening skew to Roadway $(I-34 ; n n) \quad 15$

Waterway adequacy $(I-71 ; n) \underline{6}$

Operational status $(I-41 ; X) \mathbf{A}$

Underwater Inspection Frequency $(I$ - 92B; XYY) _ N

Structure type (I - 43; nnn) 101

Year Reconstructed (I - 106) $\mathbf{0 0 0 0}$

Approach span structure type $(I-44 ; n n n) \quad \mathbf{0 0 0}$

Clear span (nnn.n ft)

Number of spans (I - 45; nnn) $\mathbf{0 0 1}$

Vertical clearance from streambed (nnn.n ft) $\underline{\mathbf{0 2 0 . 7}}$

Number of approach spans (I - 46; nnnn) $\mathbf{0 0 0 0}$

Waterway of full opening $\left(n n n . n \mathrm{ft}^{2}\right)$

Comments:

The structural inspection report of $8 / 31 / 92$ indicates that the structure is a concrete slab bridge. The abutments have small diagonal cracks and leaks reported at the top corners. Stonefill coverage is noted as good in front of the abutments and wingwalls. Cut stone blocks are noted as present in the channel under the bridge. Photos show a Vermont bench mark on top of a wingwall. The photos also show moderate channel bends near the bridge crossing. 


\section{Bridge Hydrologic Data}

Is there hydrologic data available? $\mathbf{N}$ if No, type ctrl-n $h \quad$ VTAOT Drainage area $\left(m i^{2}\right): \mathbf{1 4 . 9}$

Terrain character:

Stream character \& type: _

Streambed material: Boulders

Discharge Data (cfs): $\quad \mathrm{Q}_{2.33}-$

$\mathrm{Q}_{50} \mathbf{1 2 5 0}$

$\mathrm{Q}_{10} \frac{\mathbf{7 5 0}}{\mathbf{1 5 0 0}}$

$\mathrm{Q}_{25}$

$\mathrm{Q}_{500}$ -

Record flood date (MM / DD / YY):

Water surface elevation $(f t):-$

Estimated Discharge (cfs): _ _ Velocity at Q 25 (ft/s):

Ice conditions (Heavy, Moderate, Light): Heavy Debris (Heavy, Moderate, Light): Moderate

The stage increases to maximum highwater elevation (Rapidly, Not rapidly): -

The stream response is (Flashy, Not flashy):

Describe any significant site conditions upstream or downstream that may influence the stream's stage: -

Watershed storage area (in percent):

The watershed storage area is: - (1-mainly at the headwaters; 2- uniformly distributed; 3-immediatly upstream oi the site)

Water Surface Elevation Estimates for Existing Structure:

\begin{tabular}{|l|l|c|c|l|l|}
\hline Peak discharge frequency & $Q_{2.33}$ & $Q_{10}$ & $Q_{25}$ & $Q_{50}$ & $Q_{100}$ \\
Water surface elevation (ft) $)$ & - & $\mathbf{1 0 0 4 . 5}$ & $\mathbf{1 0 0 5 . 6}$ & $\mathbf{1 0 0 6 . 7}$ & $\mathbf{1 0 0 7 . 2}$ \\
Velocity $(\mathrm{ft} / \mathrm{sec})$ & - & - & $\mathbf{1 1 . 6}$ & - & - \\
\hline
\end{tabular}

Long term stream bed changes: -

Is the roadway overtopped below the $\mathbf{Q}_{100}$ ? (Yes, No, Unknown): $\mathbf{Y} \quad$ Frequency: $\mathbf{Q 4 0}$

Relief Elevation $(f t)$ :

Discharge over roadway at $Q_{100}\left(f t^{3} / \mathrm{sec}\right)$ :

Are there other structures nearby? (Yes, No, Unknown): $\underline{\mathbf{U}}$ Upstream distance (miles): Town: If No or Unknown, type ctrl-n os Highway No. : Structure No. : Year Built:

Clear span (ft): Clear Height (ft): Full Waterway $\left(f^{2}\right)$ : 
Downstream distance (miles): Town: Year Built:

Highway No. : Structure No. : Structure Type:

Clear span (ft): Clear Height $(f t)$ : Full Waterway $\left(f^{2}\right)$ : -

Comments:

\section{USGS Watershed Data}

Watershed Hydrographic Data

Drainage area (DA) $14.71 \mathrm{mi}^{2}$

Watershed storage (ST) $\quad \mathbf{2 . 4}$

Bridge site elevation 1009 $\mathrm{ft}$ $\%$

Main channel length

9.80 mi

$10 \%$ channel length elevation $\mathbf{1 0 8 0}$ $\mathrm{ft} \quad 85 \%$ channel length elevation $\mathrm{ft}$

Main channel slope $(S)$

(S) $\mathrm{ft} / \mathrm{mi}$

Watershed Precipitation Data

Average site precipitation in Average headwater precipitation in

Maximum 2yr-24hr precipitation event $(124,2)$ in

Average seasonal snowfall (Sn) $\mathrm{ft}$ 


\section{Bridge Plan Data}

Are plans available? $\underline{Y}$ If no, type ctrl-n pl Date issued for construction (MM/YYYY): $\underline{\mathbf{0 8}}$ / 1984

Project Number BRZ 1447(4)

Minimum channel bed elevation: $\mathbf{9 9 5 . 0}$

Low superstructure elevation: USLAB * DSLAB USRAB DSRAB -

Benchmark location description:

BM\#1, disc on a boulder, $200 \mathrm{ft}$ from left bank on left side of VT 102 toward Guildhall, elevation 1008.937. BM\#2, 12 inch spruce, spike in root $100 \mathrm{ft}$ north of intersection of TH $4 \&$ TH 5, $100 \mathrm{ft}$ off the right side of TH 4, elevation 1006.23. BM\#3, spike in tree, 12 inch spruce, 50' down TH 5 from left bank and 10 feet off right side of road, elevation 1005.41 (Continued below).

Reference Point (MSL, Arbitrary, Other): MSL Datum (NAD27, NAD83, Other): NGVD 1929 Foundation Type: 10 (1-Spreadfooting; 2-Pile; 3- Gravity; 4-Unknown)

If 1: Footing Thickness $\mathbf{0 6 . 0} \quad$ Footing bottom elevation: 991

If 2: Pile Type: $\underline{\mathbf{2 . 0}}$ (1-Wood; 2-Steel or metal; 3-Concrete) Approximate pile driven length: $\underline{\mathbf{9 9 3 . 0}}$

If 3: Footing bottom elevation: -

Is boring information available? $\mathbf{N}$ If no, type ctrl-n bi Number of borings taken: _-

Foundation Material Type: $\mathbf{3}$ (1-regolith, 2-bedrock, 3-unknown)

Briefly describe material at foundation bottom elevation or around piles:

No foundation material information available.

\section{Comments:}

BM\#4, spike in root, 18 inch balsam, 80 feet from right bank on TH 5 and 30 feet off left side of road, elevation 1015.95. Ice problems are noted on plans; in the spring of 1980, 3 feet of ice were on roadway from ice jamming at the bridge. Hydraulic data on flow $(Q)$, elevation, and velocity were taken from plans. Other elevation points located at the top of the wingwalls: upstream left 1007.64 and right 1008.85, downstream left 1007.74 and right 1008.83 . 


\section{Cross-sectional Data}

Is cross-sectional data available? $\mathbf{N}$ If no, type ctrl-n xs

Source (FEMA, VTAOT, Other)? -

Comments: There was no cross-section information available.

\begin{tabular}{|l|l|l|l|l|l|l|l|l|l|l|l|}
\hline Station & - & - & - & - & - & - & - & - & - & - & - \\
\hline Feature & - & - & - & - & - & - & - & - & - & - & - \\
\hline $\begin{array}{l}\text { Low chord } \\
\text { elevation }\end{array}$ & - & - & - & - & - & - & - & - & - & - & - \\
\hline $\begin{array}{l}\text { Bed } \\
\text { elevation }\end{array}$ & - & - & - & - & - & - & - & - & - & - & - \\
\hline $\begin{array}{l}\text { Low chord } \\
\text { to bed }\end{array}$ & - & - & - & - & - & - & - & - & - & - & - \\
\hline Station & - & - & - & - & - & - & - & - & - & - & - \\
\hline Feature & - & - & - & - & - & - & - & - & - & - & - \\
\hline $\begin{array}{l}\text { Low chord } \\
\text { elevation }\end{array}$ & - & - & - & - & - & - & - & - & - & - & - \\
\hline $\begin{array}{l}\text { Bed } \\
\text { elevation }\end{array}$ & - & - & - & - & - & - & - & - & - & - & - \\
\hline $\begin{array}{l}\text { Low chord } \\
\text { to bed }\end{array}$ & - & - & - & - & - & - & - & - & - & - & - \\
\hline
\end{tabular}

Source (FEMA, VTAOT, Other)? -There

Comments: was no cross-section information available.

\begin{tabular}{|l|l|l|l|l|l|l|l|l|l|l|l|}
\hline Station & - & - & - & - & - & - & - & - & - & - & - \\
\hline Feature & - & - & - & - & - & - & - & - & - & - & - \\
\hline $\begin{array}{l}\text { Low chord } \\
\text { elevation }\end{array}$ & - & - & - & - & - & - & - & - & - & - & - \\
\hline $\begin{array}{l}\text { Bed } \\
\text { elevation }\end{array}$ & - & - & - & - & - & - & - & - & - & - & - \\
\hline $\begin{array}{l}\text { Low chord } \\
\text { to bed }\end{array}$ & - & - & - & - & - & - & - & - & - & - & - \\
\hline Station & - & - & - & - & - & - & - & - & - & - & - \\
\hline Feature & - & - & - & - & - & - & - & - & - & - & - \\
\hline $\begin{array}{l}\text { Low chord } \\
\text { elevation }\end{array}$ & - & - & - & - & - & - & - & - & - & - & \\
\hline $\begin{array}{l}\text { Bed } \\
\text { elevation }\end{array}$ & - & - & - & - & - & - & - & - & - & - & \\
\hline $\begin{array}{l}\text { Low chord } \\
\text { to bed }\end{array}$ & - & - & - & - & - & - & - & - & - & - & \\
\hline
\end{tabular}




\section{APPENDIX E: \\ LEVEL I DATA FORM}


U. S. Geological Survey

Bridge Field Data Collection and Processing Form

Qa/Qc Check by: EW Date: $\underline{\mathbf{0 3} / \mathbf{0 5} / \mathbf{9 6}}$

\section{Structure Number MAIDTH00050006}

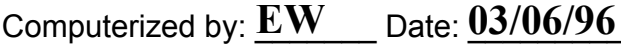

Reviewd by: LKS Date: $\underline{\mathbf{0 2} / 04 / 98}$

\section{A. General Location Descriptive}

1. Data collected by (First Initial, Full last name) E. BOEHMLER

Date $(M M / D D / Y Y)$

$\mathbf{0 7} / \mathbf{1 3} / \mathbf{1 9 9 5}$

2. Highway District Number $\mathbf{0 7}$

County Essex (009)

Waterway (I - 6) Cutler Mill Brook

Route Number TH05

3. Descriptive comments:

The bridge is located 0.05 miles from the junction of TH 5 and TH 4.
Mile marker -

Town Maidstone (42475)

Road Name -

Hydrologic Unit Code: $\mathbf{0 1 0 8 0 1 0 1}$

\section{B. Bridge Deck Observations}
4. Surface cover... LBUS 4
RBUS 6
LBDS 6
RBDS 6
Overall 6

(2b us, ds,lb,rb: 1- Urban; 2- Suburban; 3- Row crops; 4- Pasture; 5- Shrub- and brushland; 6- Forest; 7- Wetland)
5. Ambient water surface...US $\underline{2}$
UB 2
DS 1
(1- pool; 2- riffle)

6. Bridge structure type 1 (1- single span; 2- multiple span; 3- single arch; 4- multiple arch; 5-cylindrical culvert; 6- box culvert; or 7- other)
7. Bridge length 25
(feet)
Span length $\mathbf{2 3}$
(feet)
Bridge width 17.2 (feet)

\section{Road approach to bridge:}
8. LB 1
RB 2
( 0 even, 1- lower, 2- higher)
9. LB_2
RB $\underline{2}$
(1-Paved, 2- Not paved)

10. Embankment slope (run / rise in feet / foot)

US left

US right

\begin{tabular}{|c|c|c|c|}
\hline \multicolumn{2}{|c|}{ Protection } & \multirow{2}{*}{ 13.Erosion } & 14.Severity \\
\hline 11.Type & 12.Cond. & $\mathbf{0}$ & $\mathbf{0}$ \\
\hline $\mathbf{0}$ & - & $\underline{\mathbf{0}}$ & $\mathbf{1}$ \\
\hline $\mathbf{2}$ & $\mathbf{1}$ & $\underline{\mathbf{2}}$ & $\mathbf{0}$ \\
\hline $\mathbf{0}$ & - & $\mathbf{0}$ & $\mathbf{0}$ \\
\hline $\mathbf{0}$ & - & $\mathbf{0}$ & $\underline{\mathbf{0}}$ \\
\hline
\end{tabular}

Bank protection types: 0- none; 1- < 12 inches;

2- < 36 inches; 3- < 48 inches;

4- < 60 inches; 5- wall / artificial levee

Bank protection conditions: 1- good; 2- slumped;

3- eroded; 4- failed

Erosion: 0 - none; 1- channel erosion; 2 -

road wash; 3- both; 4- other

Erosion Severity: 0 - none; 1- slight; 2- moderate; 3- severe

\section{Channel approach to bridge (BF):}

15. Angle of approach: 0

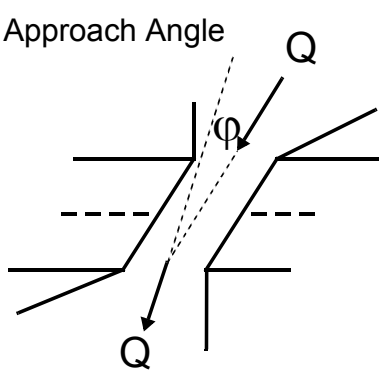

17. Channel impact zone 1 :

Where? LB $(L B, R B)$

Range? 35 feet US

Channel impact zone 2:

Where? RB (LB, RB)

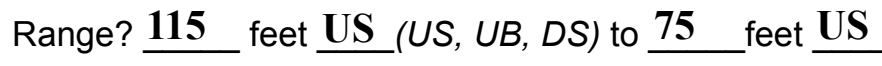
Impact Severity: 0- none to very slight; 1-Slight; 2- Moderate; 3- Severe
16. Bridge skew: 35 Bridge Skew Angle

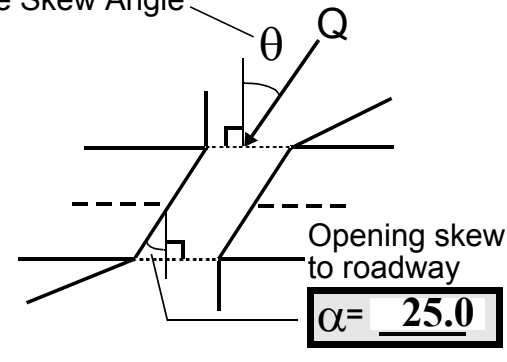

\section{Exist? $\underline{\mathbf{Y}}(\mathrm{Y}$ or $N)$}

Severity 2

US, UB, DS) to $\underline{\mathbf{0}}$ feet $\underline{\mathbf{D S}}$

Exist? $\mathbf{Y}(\mathrm{Y}$ or $N)$

Severity $\underline{2}$ 
18. Bridge Type: 1a

1a- Vertical abutments with wingwalls

$1 \mathrm{~b}$ - Vertical abutments without wingwalls

2- Vertical abutments and wingwalls, sloping embankment Wingwalls parallel to abut. face

3- Spill through abutments

4- Sloping embankment, vertical wingwalls and abutments

Wingwall angle less than $90^{\circ}$.

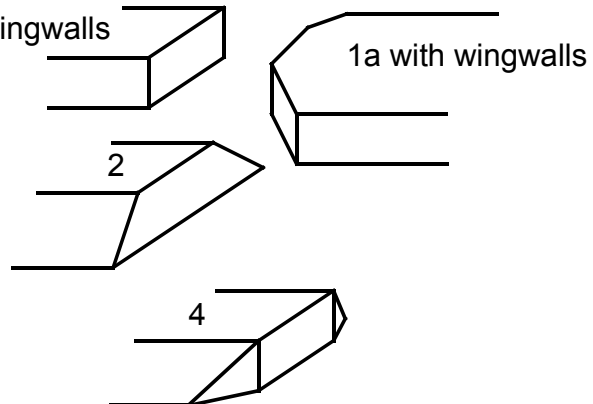

19. Bridge Deck Comments (surface cover variations, measured bridge and span lengths, bridge type variations, approach overflow width, etc.)

\#4: USLB - pasture, with forest bisected by TH4 beyond two bridge lengths

DSLB - very small area of grass along channel, then forest area

DSRB - very small area of grass along channel, then forest area

USRB - small area of grass, behind wingwalls, with forest beyond the area bisected by THS.

\#7: Bridge dimension values are from VTAOT form. Field measured values include bridge length, 25 feet; span length, $22.5 \mathrm{ft}$; and bridge width, 17.2 feet.

\#13: Erosion is evident from road wash behind the upstream right wingwall area (a small gully is present). This erosion may have affected the support material beneath the road. A storm drainage ditch is also present in the upstream right wingwall area.

\section{Upstream Channel Assessment}

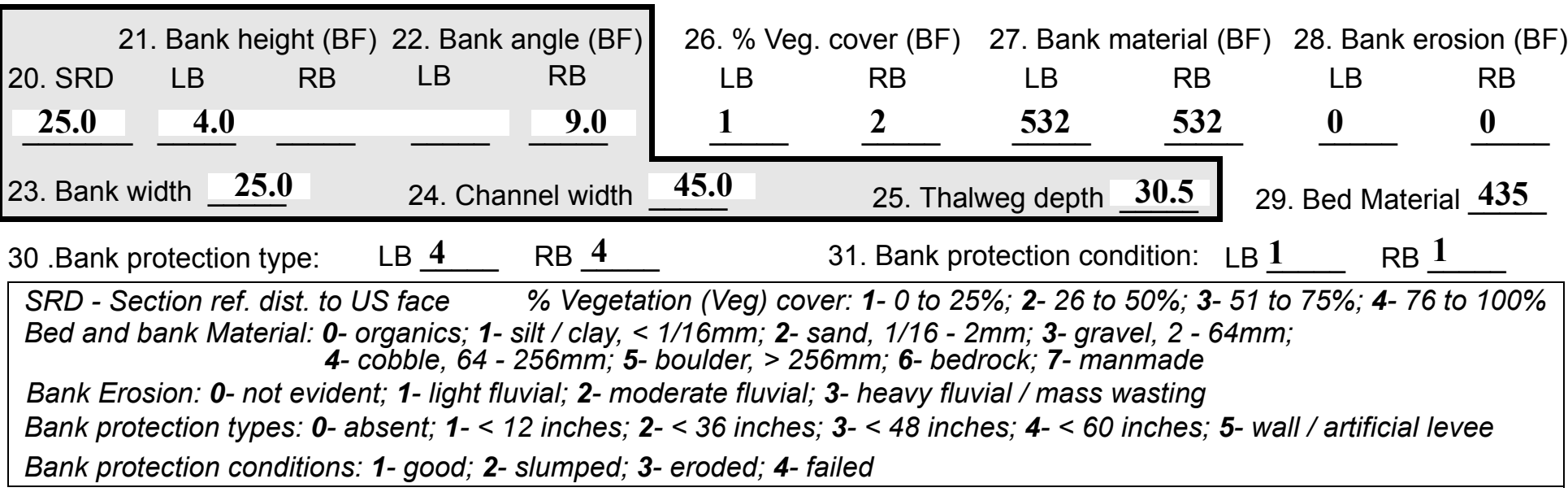

32. Comments (bank material variation, minor inflows, protection extent, etc.):

\#27/29: There is a higher fraction of sand material in the banks compared to the bed. Cobbles and gravel in the bed are tightly embedded in the sand and fine gravel material.

\#30/31: RB protection extends from $100 \mathrm{ft}$ US to the US end of the USRWW. LB protection extends from $75 \mathrm{ft}$ US to the US end of the USLWW. The protection consists of very large type-4 boulders US and grades to type-3 quarried stone blocks (less than 48 inches diameter) just US of the USLWW. 
33.Point/Side bar present? $\mathbf{N}(Y$ or $N$. if $N$ type ctrl-n pb)34. Mid-bar distance: -

35. Mid-bar width: -

36. Point bar extent: feet (US, UB) to feet (US, UB, DS) positioned $\%$ LB to $\% \mathrm{RB}$

37. Material: -

38. Point or side bar comments (Circle Point or Side; Note additional bars, material variation, status, etc.):

There are no pointbars upstream at this site.

39. Is a cut-bank present? $\underline{\mathbf{N}}$ (Y or if $\mathrm{N}$ type ctrl-n cb)

40. Where? (LB or $R B)$

41. Mid-bank distance: -

42. Cut bank extent: feet (US, UB) to feet (US, UB, DS)

43. Bank damage: ( 1- eroded and/or creep; 2- slip failure; 3- block failure)

44. Cut bank comments (eg. additional cut banks, protection condition, etc.):

There are no cut-banks upstream at this site.

\section{Is channel scour present? $\mathbf{N}$ ( $Y$ or if $N$ type ctrl-n cs)}

47. Scour dimensions: Length Width Depth : 46. Mid-scour distance: -

48. Scour comments (eg. additional scour areas, local scouring process, etc.):

There is no channel scour present upstream at this site.

\section{Are there major confluences? $\mathbf{N}$}

51. Confluence 1: Distance Confluence 2: Distance 52. Enters on Enters on 54. Confluence comments (eg. confluence name):

There are no major confluences upstream at this site.
50. How many? -

53. Type(1-perennial; 2- ephemeral) Type (1-perennial; 2- ephemeral)

\section{Under Bridge Channel Assessment}

55. Channel restraint (BF)? LB 2

\begin{tabular}{|c|c|c|c|}
\hline 56. & t $(B F)$ & 57 Angle & \\
\hline LB & RB & LB & $\mathrm{RP}$ \\
\hline & & 1.0 & \\
\hline
\end{tabular}

58. Bank width (BF) (1- natural bank; 2- abutment; 3- artificial levee)

Bed and bank Material: 0- organics; 1- silt / clay, < 1/16mm; 2- sand, 1/16 - 2mm; 3- gravel, 2 - 64mm; 4- cobble, 64 - 256mm; 5- boulder, > 256mm; 6- bedrock; 7- manmade

61. Material $(\mathrm{BF}) \quad$ 62. Erosion $(\mathrm{BF})$

LB RB LB RB

$\underline{2} \quad \underline{7} \quad \underline{-}$

59. Channel width

60. Thalweg depth $\mathbf{9 0 . 0}$

63. Bed Material -

Bank Erosion: 0- not evident; 1- light fluvial; 2- moderate fluvial; 3- heavy fluvial / mass wasting

64. Comments (bank material variation, minor inflows, protection extent, etc.):

7

\#63: The bed material is composed of stone fill, boulders, cobbles, and gravel. 
65. Debris and Ice Is there debris accumulation?

$(Y$ or $N)$ 66. Where? $\mathbf{N}$

(1- Upstream; 2- At bridge; 3- Both)

67. Debris Potential ( 1- Low; 2- Moderate; 3- High)

68. Capture Efficiency 2

(1-Low; 2- Moderate; 3- High)

69. Is there evidence of ice build-up? 3 (Y or $N)$

Ice Blockage Potential $\mathbf{N}$

(1- Low; 2- Moderate; 3- High)

70. Debris and Ice Comments:

3

\#68: A bend in the channel, boulders on the US banks, and the large opening angle increase the potential for debris to accumulate. The historical data form indicates that ice buildup problems have occurred in the past. The channel does not meander so debris is somewhat unlikely to get into the channel from erosion.

\begin{tabular}{|l|c|c|c|c|c|c|c|c|}
\hline Abutments & $\begin{array}{c}\text { 71. Attack } \\
\angle \text { (BF) }\end{array}$ & $\begin{array}{c}\text { 72. Slope } \angle \\
\text { (Qmax) }\end{array}$ & $\begin{array}{c}\text { 73. Toe } \\
\text { loc. (BF) }\end{array}$ & $\begin{array}{c}\text { 74. Scour } \\
\text { Condition }\end{array}$ & $\begin{array}{c}\text { 75. Scour } \\
\text { depth }\end{array}$ & $\begin{array}{c}\text { 76. Exposure } \\
\text { depth }\end{array}$ & 77. Material & 78. Length \\
\hline LABUT & & $\mathbf{1 5}$ & $\mathbf{9 0}$ & $\mathbf{2}$ & $\mathbf{0}$ & $\mathbf{0}$ & $\mathbf{0}$ & $\mathbf{9 0 . 0}$ \\
\hline RABUT & $\mathbf{1}$ & - & $\mathbf{9 0}$ & & & $\mathbf{2}$ & $\mathbf{0}$ & $\mathbf{1 9 . 0}$ \\
\hline
\end{tabular}

Pushed: $L B$ or RB

Toe Location (Loc.): 0- even, 1- set back, 2- protrudes

Scour cond.: 0- not evident; 1- evident (comment); 2- footing exposed; 3-undermined footing; 4- piling exposed; 5- settled; 6- failed

Materials: 1- Concrete; 2- Stone masonry or drywall; 3- steel or metal; 4- wood

79. Abutment comments (eg. undermined penetration, unusual scour processes, debris, etc.):

$\mathbf{0}$

0

1

The abutments are well protected.

80. Wingwalls:

Exist? Material? Scour Scour Exposure $\begin{aligned} & 81 . \\ & \text { Angle? Length? }\end{aligned}$ Condition? depth? depth?

USLWW:

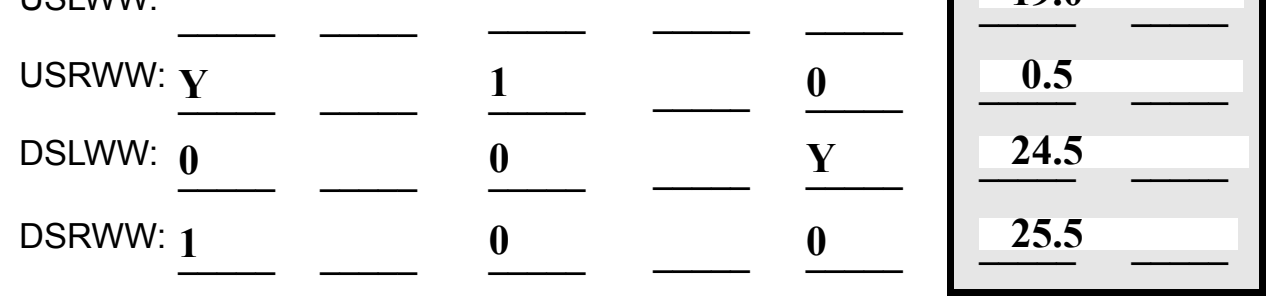

Wingwall materials: 1- Concrete; 2- Stone masonry or drywall; 3- steel or metal; 4- wood

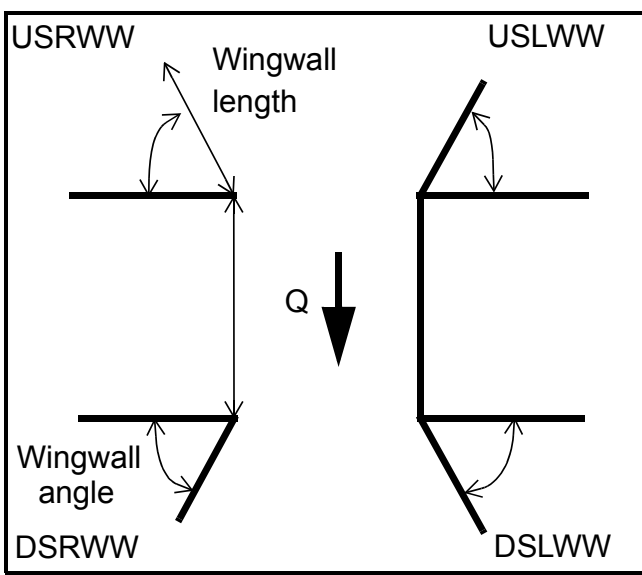

82. Bank / Bridge Protection:

\begin{tabular}{|l|l|l|l|l|l|l|l|c|}
\hline Location & USLWW & USRWW & LABUT & RABUT & LB & RB & DSLWW & DSRWW \\
\hline Type & $\mathbf{0}$ & $\mathbf{0}$ & $\mathbf{Y}$ & $\mathbf{0}$ & $\mathbf{1}$ & $\mathbf{1}$ & $\mathbf{1}$ & $\mathbf{1}$ \\
\hline Condition & $\mathbf{Y}$ & $\mathbf{0}$ & $\mathbf{1}$ & $\mathbf{0}$ & $\mathbf{1}$ & $\mathbf{1}$ & $\mathbf{1}$ & $\mathbf{1}$ \\
\hline Extent & $\mathbf{1}$ & $\mathbf{0}$ & $\mathbf{0}$ & $\mathbf{3}$ & $\mathbf{3}$ & $\mathbf{3}$ & $\mathbf{3}$ & - \\
\hline
\end{tabular}

Bank / Bridge protection types: 0- absent; 1- < 12 inches; 2- < 36 inches; 3- < 48 inches; 4- < 60 inches; 
83. Wingwall and protection comments (eg. undermined penetration, unusual scour processes, etc.):

-
-
-
-
-
3
1
1
3
1
3

\section{Piers:}

84. Are there piers? Th (Y or if N type ctrl-n pr)

\begin{tabular}{|l|l|l|l|l|l|l|l|}
\hline \multirow{2}{*}{$\begin{array}{l}85 . \\
\text { Pier no. }\end{array}$} & \multicolumn{3}{|c|}{ width (w) feet } & \multicolumn{5}{c|}{ elevation (e) feet } \\
\cline { 2 - 8 } & w1 & w2 & w3 & e@w1 & e@w2 & e@w3 \\
\hline Pier 1 & & $\mathbf{9 . 0}$ & & $\mathbf{5 5 . 0}$ & $\mathbf{3 0 . 0}$ & $\mathbf{2 2 . 0}$ \\
\hline Pier 2 & & & & $\mathbf{3 5 . 0}$ & $\mathbf{1 4 . 5}$ & $\mathbf{5 0 . 0}$ \\
\hline Pier 3 & & - & - & $\mathbf{1 3 . 5}$ & - & - & w1 \\
\hline Pier 4 & - & - & - & - & - & - & w2 \\
\hline
\end{tabular}

\begin{tabular}{|l|l|l|l|l|}
\hline Level 1 Pier Descr. & \multicolumn{1}{|c|}{1} & \multicolumn{1}{|c|}{2} & \multicolumn{1}{|c|}{3} & 4 \\
\hline 86. Location (BF) & e wing- & the & covers & \\
\hline 87. Type & wall & wing & pri- & \\
\hline 88. Material & pro- & wall & mari & \\
\hline 89. Shape & tec- & base & aly & \\
\hline 90. Inclined? & tion & s, & the & N \\
\hline 91. Attack $\angle$ (BF) & cov- & exce & DS & - \\
\hline 92. Pushed & ers & pt on & end. & - \\
\hline 93. Length (feet) & - & - & - & - \\
\hline 94. \# of piles & the & the & & - \\
\hline 95. Cross-members & entir & DSR & & - \\
\hline 96. Scour Condition & e & WW, & & - \\
\hline 97. Scour depth & lengt & wher & & - \\
\hline 98. Exposure depth & h of & e it & & - \\
\hline
\end{tabular}

LFP, LTB, LB, MCL, MCM, MCR, RB, RTB, RFP

1- Solid pier, 2- column, 3- bent

1-Wood; 2- concrete; 3- metal; 4- stone

1- Round; 2- Square; 3- Pointed

Y-yes; $N$ - no

$L B$ or $R B$

0- none; 1- laterals; 2- diagonals; 3- both

0- not evident; 1- evident (comment);

2- footing exposed; 3- piling exposed;

4- undermined footing; 5- settled; 6- failed 
99. Pier comments (eg. undermined penetration, protection and protection extent, unusual scour processes, etc.):

-
-
-
-
-
-
-
-
-

100.

\section{E. Downstream Channel Assessment}

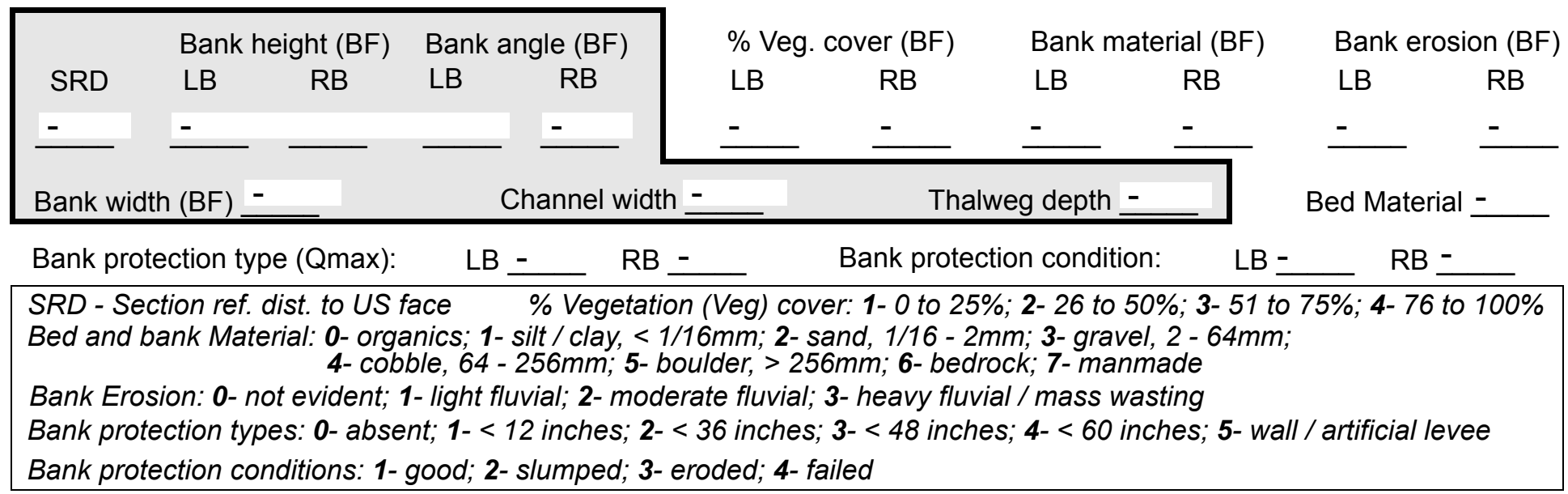

Comments (eg. bank material variation, minor inflows, protection extent, etc.):

$-$

$-$

-

$-$

$-$

$-$

$-$

$-$

$-$

$-$

$-$

$-$

$-$

$-$

$-$

101. Is a drop structure present? _ ( $Y$ or $N$, if $N$ type ctrl-n ds) 102. Distance: ___ feet 103. Drop: -_ feet 104. Structure material: ___ (1- steel sheet pile; 2- wood pile; 3- concrete; 4- other) 105. Drop structure comments (eg. downstream scour depth):

$-$

$-$

There are no piers. 
106. Point/Side bar present? (Y or N. if $N$ type ctrl-n pb) Mid-bar distance:

Mid-bar width:

Point bar extent: feet

(US, UB, DS) to feet (US, UB, DS) positioned $\underline{2}$ \%LB to $\underline{\mathbf{2}} \%$ RB

Point or side bar comments (Circle Point or Side; note additional bars, material variation, status, etc.):

\section{3}

0

0

435

Is a cut-bank present? 3 (Y or if $N$ type ctrl-n cb) Where? $\underline{4}$ (LB or RB) Mid-bank distance: 1 Cut bank extent: 1 feet $\underline{\mathbf{T h}}$ (US, UB, DS) to $\underline{\mathbf{e}}$ feet ove (US, UB, DS)

Bank damage: rba (1- eroded and/or creep; 2- slip failure; 3- block failure)

Cut bank comments (eg. additional cut banks, protection condition, etc.):

nk vegetation cover is greater than 90 percent 50 feet DS of the bridge. The bank material DS has more gravel than the US banks, which are predominantly sand. The protection on the left and right banks extends from the ends of the wingwalls to 70 feet DS. The protection is type 4 to $45 \mathrm{ft}$ DS then type-3 to $70 \mathrm{ft}$ DS.

Is channel scour present? ( $Y$ or if $N$ type ctrl-n cs)

Mid-scour distance:

Scour dimensions: Length Width Depth:

Positioned $\%$ LB to $\% \mathrm{RB}$

Scour comments (eg. additional scour areas, local scouring process, etc.):

$\mathbf{N}$

Are there major confluences? - (Yor if $N$ type ctrl-n $m c)$ Confluence 1: Distance e is Enters on $\underline{\text { no }}$ (LB or $R B)$ How many? Ther Confluence 2: Distance $\underline{\mathbf{p}}$ Enters on stru (LB or RB) Type dro (1-perennial; 2- ephemeral) Type ctur (1-perennial; 2- ephemeral) Confluence comments (eg. confluence name):

e at this site.

\section{F. Geomorphic Channel Assessment}

107. Stage of reach evolution

1- Constructed

2- Stable

3- Aggraded

4- Degraded

5- Laterally unstable

6- Vertically and laterally unstable 
108. Evolution comments (Channel evolution not considering bridge effects; See HEC-20, Figure 1 for geomorphic descriptors):

$\mathbf{N}$

$-$

$-$

$-$

$-$

$-$

$-$

-

$-$ 


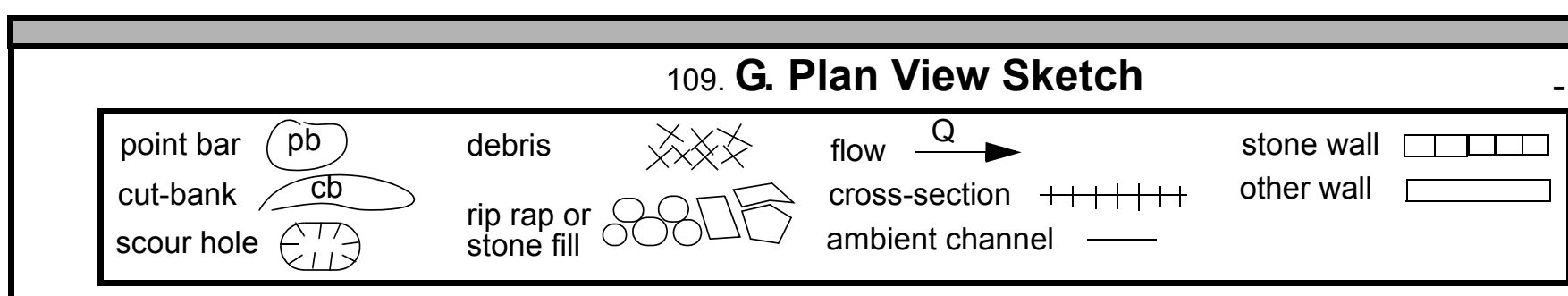

cut-bank $\mathrm{cb}$

scour hole rip rap or
stone fill stone fill cross-section $+1+1+1$ ambient channe other wall 
APPENDIX F:

SCOUR COMPUTATIONS 
SCOUR COMPUTATIONS

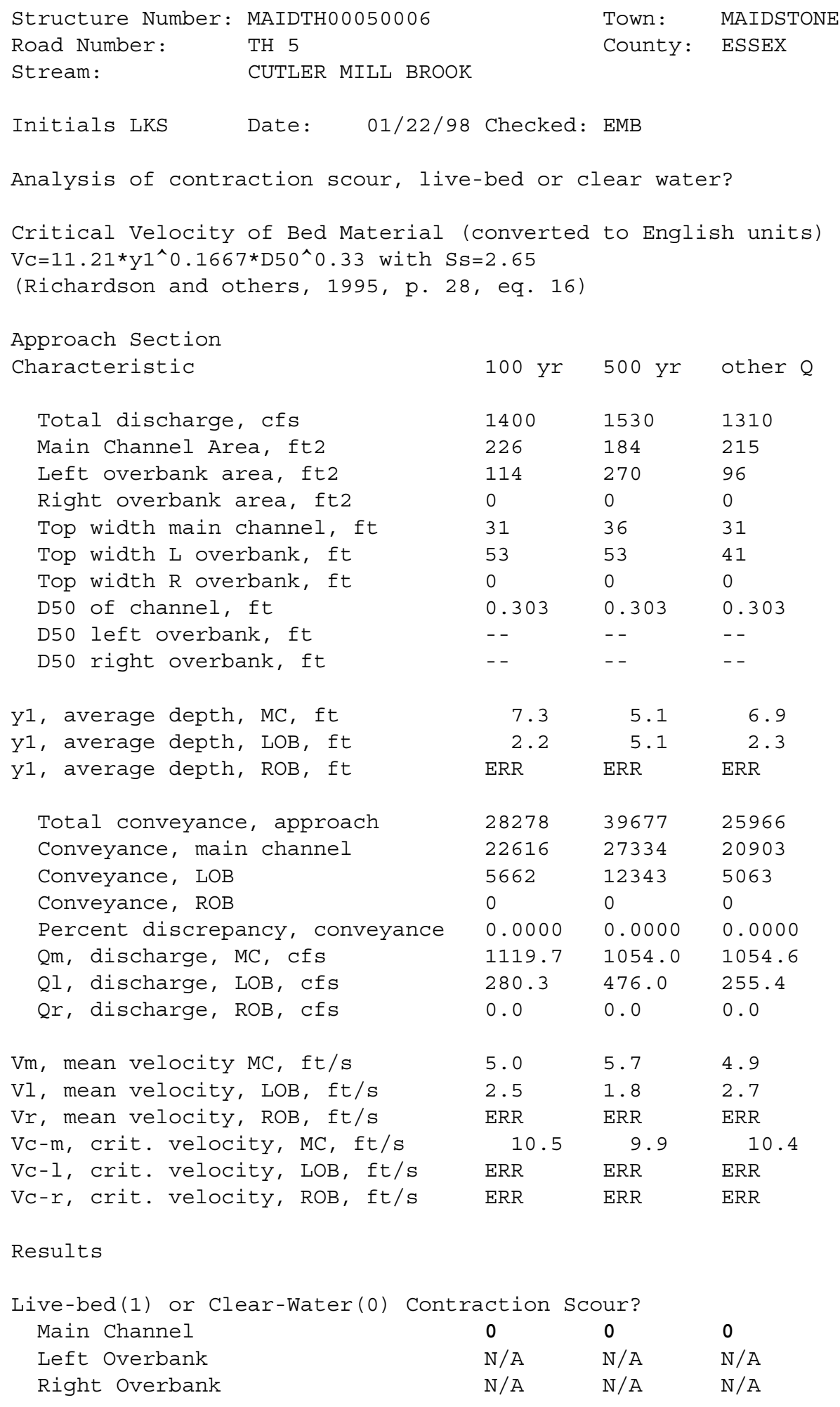




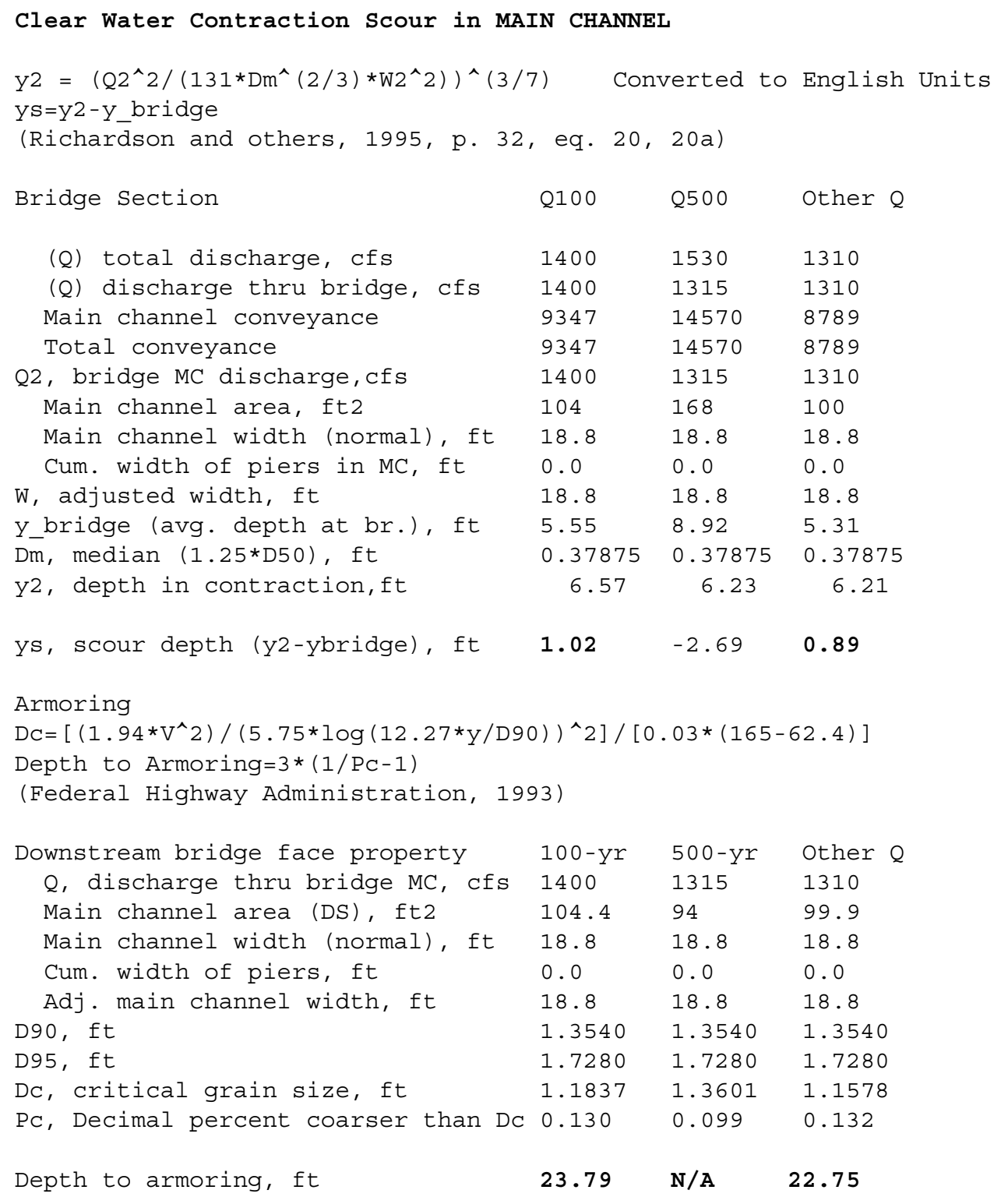




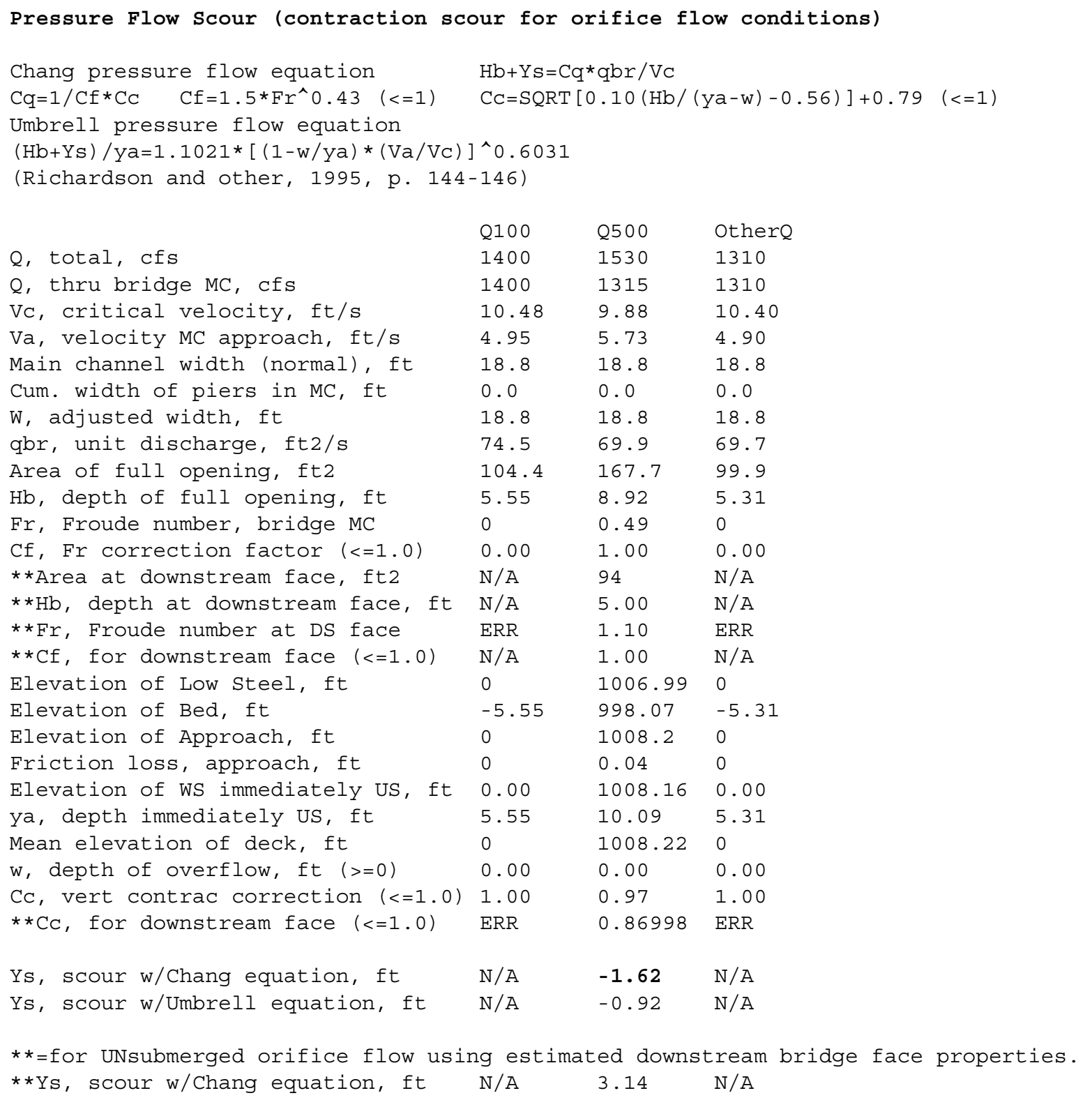




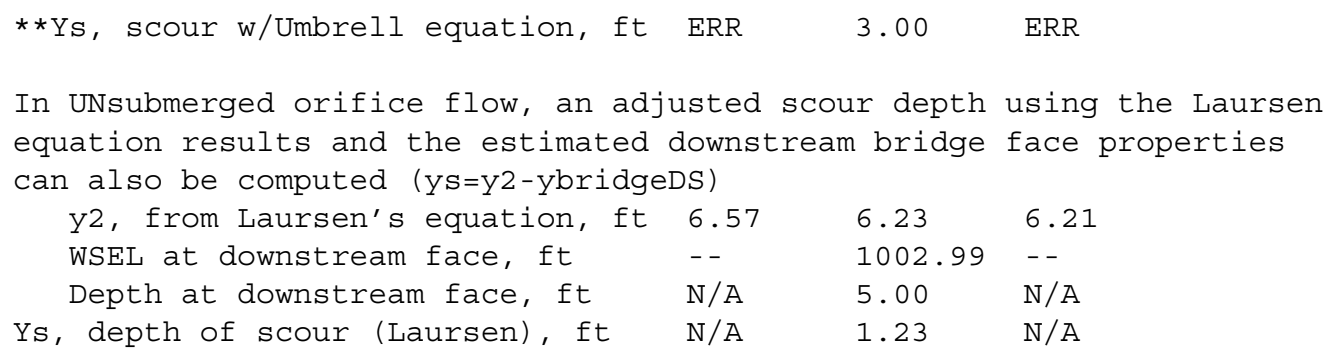

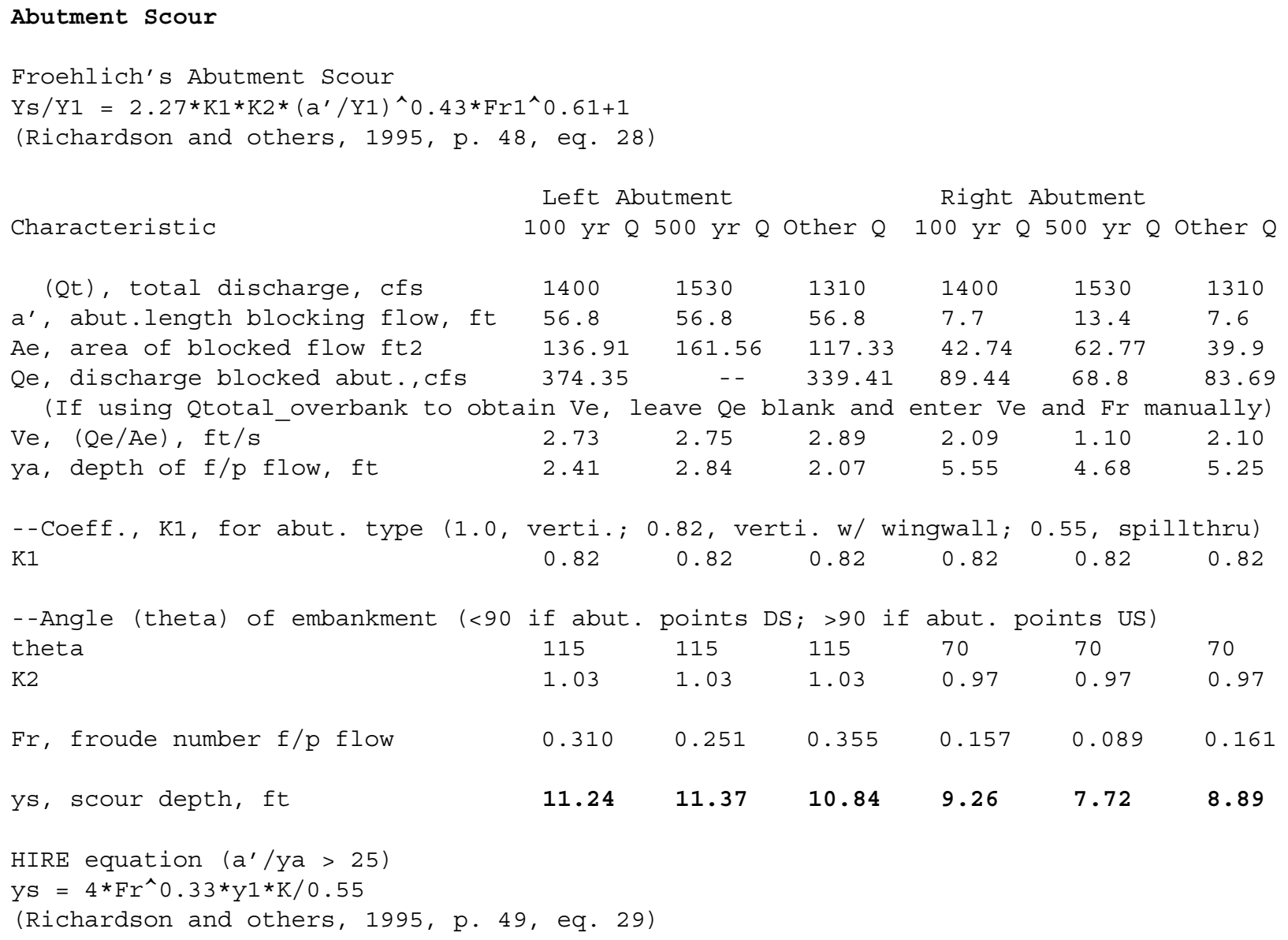




\begin{tabular}{|c|c|c|c|c|c|c|}
\hline$a^{\prime}$ (abut length blocked, ft) & 56.8 & 56.8 & 56.8 & 7.7 & 13.4 & 7.6 \\
\hline y1 (depth f/p flow, ft) & 2.41 & 2.84 & 2.07 & 5.55 & 4.68 & 5.25 \\
\hline$a^{\prime} / y 1$ & 23.56 & 19.97 & 27.50 & 1.39 & 2.86 & 1.45 \\
\hline Skew correction (p. 49, fig. 16) & 1.00 & 1.00 & 1.00 & 1.00 & 1.00 & 1.00 \\
\hline Froude no. f $/ p$ flow & 0.31 & 0.25 & 0.35 & 0.16 & 0.09 & 0.16 \\
\hline Ys w/ corr. factor $\mathrm{K} 1 / 0.55$ : & $E R R$ & ERR & 10.67 & ERR & $E R R$ & ERR \\
\hline vertical w/ ww's & $\mathrm{ERR}$ & $\mathrm{ERR}$ & 8.75 & $\mathrm{ERR}$ & $\mathrm{ERR}$ & $\mathrm{ERR}$ \\
\hline spill-through & ERR & ERR & 5.87 & ERR & ERR & ERR \\
\hline Abutment riprap Sizing & & & & & & \\
\hline Isbash Relationship & & & & & & \\
\hline $\begin{array}{l}\mathrm{D} 50=\mathrm{Y}^{*} \mathrm{~K} * \mathrm{Fr} \mathrm{r}^{\wedge} 2 /(\mathrm{Ss}-1) \text { and } \mathrm{D} 50=\mathrm{Y}^{*} \mathrm{~K} *( \\
\text { (Richardson and others, 1995, p11 }\end{array}$ & $\begin{array}{l}\wedge \\
2) \wedge 0.1 \\
\text { eq. } 81\end{array}$ & (S) & & & & \\
\hline Characteristic & Q100 & Q500 & Other $Q$ & Q100 & Q500 & Other $\mathrm{Q}$ \\
\hline Fr, Froude Number & 1 & 1 & 1 & 1 & 1 & 1 \\
\hline y, depth of flow in bridge, ft & 5.55 & 5.00 & 5.31 & 5.55 & 5.00 & 5.31 \\
\hline Median stone Diameter for riprap & : left & utment & & right & abutment, & ft \\
\hline Fr<=0.8 (vertical abut.) & ERR & ERR & ERR & ERR & ERR & ERR \\
\hline Fr>0.8 (vertical abut.) & 2.32 & 1.85 & 2.22 & 2.32 & 1.85 & 2.22 \\
\hline
\end{tabular}

